\title{
Ethnobiology and Shifting Baselines: An Example Reinterpreting the British Isles' Most Detailed Account of a Sea Serpent Sighting as Early Evidence for Pre-Plastic Entanglement of Basking Sharks
}

Robert L. France

\begin{abstract}
Recognizing shifts in baseline conditions is necessary for understanding long-term changes in populations as a prelude to implementing present-day management actions and setting future restoration goals for anthropogenically-altered marine ecosystems. Examining historical information contained within anecdotal accounts from non-traditional sources has previously proven useful in this regard. Herein, I scrutinize eyewitness accounts and accompanying illustrations published in nineteenth-century natural history journals which together comprise the most detailed description of sighting a purported sea serpent in the British Isles. I then reinterpret this anecdote (as well as complementary evidence offered by cryptozooloogists in its support obtained from other published journal articles of similarly described unidentified marine objects), suggesting it to provide one of the earliest reports of the non-lethal entanglement of an animal-in this case what I believe to have been a basking shark-in European waters. The present work suggests that the entanglement of sharks in fishing gear or hunting equipment has a much longer environmental history than is commonly believed, and provides another example of how ethnozoological studies can contribute toward recognizing past fishing-related pressures and baseline shifts in affected populations. Sharks, it seems, have been subjected to the impacts of not just direct fishery exploitation but also through becoming by-catch, long before the advent and widespread use of plastic in the middle of the twentieth century.
\end{abstract}

Keywords: Scotland, 19th-Century; Sea Serpents; Non-Lethal Entanglement; Basking Sharks

Ocean Research Group, Department of Plants, Food and Environmental Science, Dalhousie University, PO Box 550, Truro, Nova Scotia Canada, B2N 4P8,

*Corresponding author. $\square$ E-mail address: rfrance@dal.ca

\section{INTRODUCTION}

Ecosystems are very much shaped by both past actions and corresponding societal attitudes (e.g. Cronon and McDonnell 1993; France 2007; Szabo and Hedl 2010). In consequence, and in order to avoid its practice and proscriptions being incomplete, conservation biology needs to expand its historical perspective (Crumley 1994; Meine 1999). For example, the abundance and biodiversity of marine fauna in the north Atlantic has been seriously altered through human actions (e.g. Lotze et al. 2006). Much 
of the recognition for this has come from quantitative reanalyses of historical fishery records. Mowat (1999), however, provides equally valuable evidence for such declines based on the qualitative (i.e. textural) examination of historical accounts from eyewitnesses. The scholarly process of studying dynamic relationships between people, biota, and their environment in both present as well as past times falls within the bailiwick of ethnobiology (Anderson et al. 2011).

One way for ethnobiology to contribute to the discipline of historical ecology is through the use of anecdotal information, often compiled from a wide variety of nonstandard sources (da Silva et al. 2014). Such information (e.g. Al-Abdulrazzak et al. 2012; McClenachan et al. 2012; SaenzArroyo et al. 2005, 2006) can be used to help to address the conundrum facing conservation biologists posed by the "shifting baseline syndrome" (sensu Pauly 1995), wherein each generation successively redefines what is deemed "natural" according to its own temporally truncated view of an increasingly depauperate and biodiversity-impoverished

world. Understanding pre-anthropogenic baseline conditions is deemed essential for designing effective present-day management activities as well as for setting future restoration goals in complex social-ecological systems (e.g. Pitcher 2005; Narchi et al. 2013).

Ethnozoology entails the ecological, cognitive, and symbolic study of fauna (Alves and Albuquerque 2017), irrespective of whether those animals are real or imaginary (e.g. Tidermann and Gosler 2010; Da Silva Vieira et al. 2017; Leclercq-Marx 2018). Then there are the intriguing inbetween cases of actual animals misinterpreted as mythological ones (McGowan-Hartman 2013). Parsons (2004), for example, suggested that folkloric tales of sea monsters, in particular those from Scotland, home to a rich panoply of such (Hamilton 2003), may provide antecedent information useful for interpreting historical changes in biogeography. Re-examining the "data" (sensu Paxton 2009) imbedded in historical anecdotes of sea monster encounters can indeed yield ethnobiological insights (Paxton and Naish 2019). Not without reason, therefore, did Bolster (2012:91) state that "no marine environmental historian worth his or her salt can afford to ignore...nineteenth-century sea serpents."

In this paper, I explore another example of how the use of non-standard documentary sources can provide insight about historical baseline conditions for important species of marine fauna. Specifically, the aim of the investigation was to carefully parse eyewitness descriptions and to scrutinize illustrations of the sighting made from the vessel Leda in the Scottish Hebrides in 1872 of an unidentified marine object (UMO), identified at the time as being a sea serpent. I then, by way of the literary conceit of a hypothetical moot court case, examine and reinterpret this anecdote, suggesting it to provide some of the first evidence for the non-lethal pre-plastic entanglement of a marine animal in European waters. The supposition is of course that: (a) sea serpents do not now, and never have, existed in the form commonly perceived in modern cryptozoological lore; and (b) that almost all sightings of sea serpents can be explained by natural phenomena (France 2019; Loxton and Prothero 2015). It is hoped that this work will demonstrate the importance to conservation biology in recognizing the utility of such qualitative historical ethnobiology research, such as originally proposed by Paul (1995) and as 
purposely reiterated by an anonymous reviewer of the present manuscript.

During the nineteenth century, sea serpents were considered by many, including a cadre of the world's leading natural scientists (Lyons 1999; McGowanHartman 2013; France 2019), to be real animals meritorious of study. Today, with the exception of cryptozoologists who continue believe in such (Dendle 2006; Rossi 2016), despite all evidence to the contrary (Loxton and Prothero 2015; Williams 2015; France 2019), the benefit of greater scientific knowledge has resulted in aquatic monsters being parsimoniously explained (i.e. "Occam's Razor" - Das 2009) by either known and at-the-time unrecognized animals (Brongersma 1968; Paxton and Holland 2005; Paxton et al. 2005; Brink-Roby 2008; Woodley et al. 2011; Galbreath 2015), natural phenomena (Lehn 1979; Lehan and Schroeder 1981; Binns 1984), or anthropogenic accretions (France 2016a,b, 2017, 2018, 2019).

There is a good case to be made for focusing in on the particulars of the 1872 Leda incident, as it has been referred to as being the "most detailed account of a sea serpent encounter" in the British Isles (Harrison 2001:153). Indeed, of all the hundreds of reports about sea serpents from Europe (Oudemans 1892; Heuvelmans 1968), that pertaining to the Leda encounter comes closest, in terms of the number and nature of the eyewitness observations, to matching those for the "Gloucester Sea Serpent" of New England and New York (Soini 2010), which remains the most sighted and studied UMO in history (Davis et al. 1817; Brown 1990; Burns 2014), and one whose anecdotes about which frequently and explicitly liken the creature's body to resembling a string of entangled fishing net gear or maritime debris (Fama 2012; France
2019). In terms of the latter, conservation biology-themed, illation for an UMO, the Leda "sea serpent" therefore serves as the singular Old World equivalent to the much more famous Gloucester or "Great New England Sea Serpent" (O'Neill 1999); one set of sightings occurring near the beginning, and the other toward the end, of the nineteenth-century, both I propose, being anthropogenic by-products of the rapid and rapacious expansion of fishing and hunting pressure on marine fauna during that time.

\section{MATERIAL AND METHODS}

\section{The Leda Account, its Times and Significance}

Throughout the nineteenth century, and during the Victorian Age in particular, middleand upper-class Britons occupied their leisure by enthusiastically engaging in natural history pursuits. Naturalist social clubs and avocational societies flourished, lecture series were frequent, and trips to the countryside and seashore for collecting specimens were de rigueur. There was hardly a drawing-room that did not contain a curiosity cabinet, fern-case, shell collection, or live aquarium in which to display the results of one's personal gleanings and study (Barber 1980; Mason 2017). Natural history became an obsession, with books about such outselling novels from the likes of Dickens, Thackeray, Eliot, and Hardy in the latter decades of the century.

Imagine a gentleman or a lady, sitting in his Glasgow study or her Edinburgh solar in the spring of 1873, and opening the May issue of The Zoologist, a monthly journal of natural history popular in educated society, that ran from 1843 to 1916 , that was edited by noted entomologist and botanist Edward 
Newman (Figure 1). There, between pages 3517-3522, they would have found the letter entitled "Appearance of an Animal, believed to be that which is called the Norwegian Sea-Serpent, on the Western Coast of Scotland, in August, 1872," written by the Reverend John Macrae and the Reverend David Twopeny, the former, the Minister of Glenelg, Invernesshire, and the latter, the Vicar of Stockbury, Kent. Three facets about the article would have nary raised an eyebrow of surprise by a learned reader as being anything out of the ordinary, whereas one most certainly was exceptional, which would have elicited him or her to sit upright in their chairs, with either an "I-told-you-so"

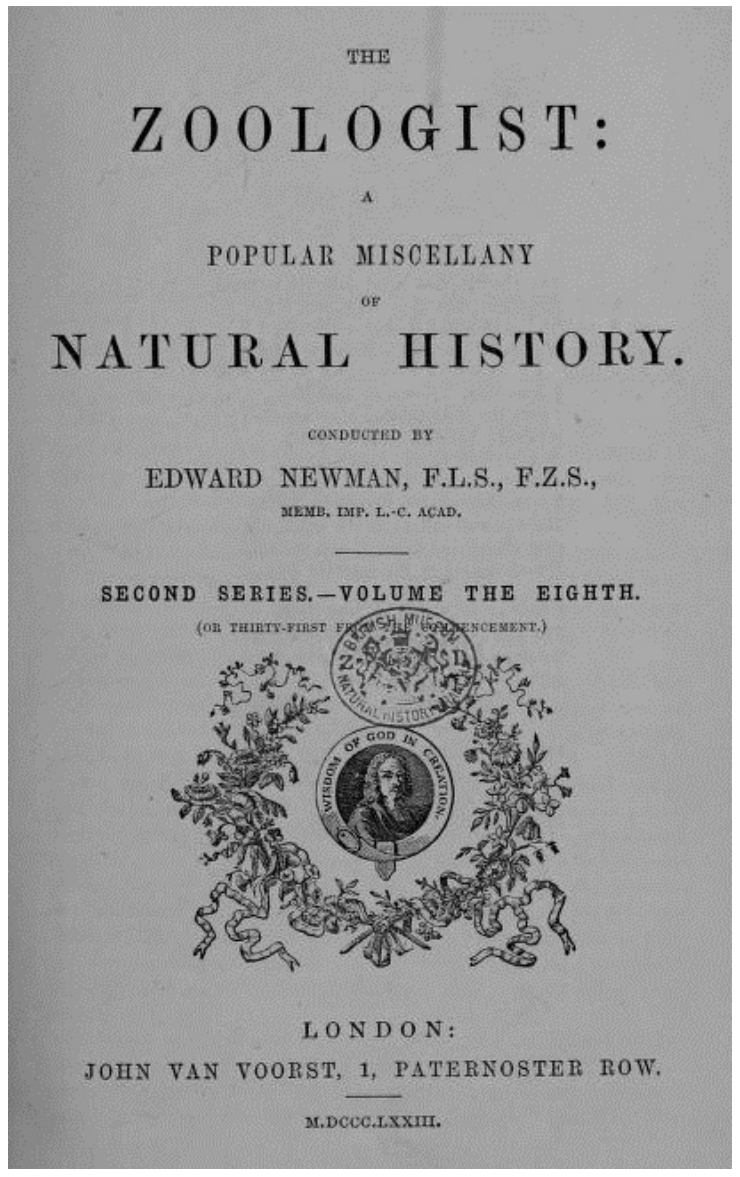

Figure 1. Cover of the 1873 issue of the natural history journal that contained the report of the Leda unidentified marine object (UMO), the most detailed description of a putative sea serpent observed in British Isles waters. This and all subsequent images are in the Public Domain. nod of their heads, or a loud exclamation of "bosh!" or "humbug!" depending on what might today be called their respective "Mulder-esque or Scully-like" X-Files predilection.

That a science-based journal of international reputation would have run an article about sea serpents was commonplace for the time. Many of the world's leading natural scientists, including the likes of Sirs Richard Owen, Charles Lyell, and Joseph Banks, considered the study of sea serpents to be not only a legitimate but also a meritorious field of scholarship (Brown 1990; Lyons 2009; France 2019). This was particularly so in relation to the avalanche of paleontological discoveries that were then being unearthed (Barber 1980; Regal 2012; McGowanHartman 2013; Loxton and Prothero 2015), and how animals from the antediluvian past were related to present-day creatures (Ritvo 1997). In consequence, in addition to The Zoologist, dozens of articles on sea serpents were published in other prestigious scholarly journals such as Nature and American Naturalist (Westrum 1979), including Scotland's own Proceedings of the Royal Society of Edinburgh and the Memoirs of the Wernerian Natural History Society, as well as a flurry of contemporaneous books: Sea Monsters Unmasked (1883), Mythical Monsters (1886), Monsters of the Sea: Legendary and Authentic (1890), The Great Sea-Serpent: An Historical and Critical Treatise (1892).

That it was in the Hebrides on the northwest edge of Scotland where a sea serpent was observed was also no big surprise. For did not history inform that such northern waters harboured monstrous denizens of the deep (e.g. Svanberg 1999; Houwen and Olsen 2001; Starkey 2017; Szabo 2018; Jacquemard et al. 2018), 
something known and generally accepted, as reflected in the article's very title, since the 1755 English publication of Bishop Pontopiddian's highly influential The Natural History of Norway? And of course, Scottish mythology has long populated its resident waters with all manner of mysterious beings (e.g. Tiet 1918; Parsons 2004). For example, "Nessie" did not arise de novo in 1933 by accident in her eponymous loch. She owed her commotion-filled debut (sensu Williams 2015) to a fusion of the image of a plesiosaur and humans garnered from the then-screening King Kong with that of widely-held folkloric beliefs in the existence of kelpie water horses (Loxton and Prothero 2015). In fact, one of the earliest modern encounters of international renown with a purported sea monster occurred in 1808 on the Orkney island of Stronsay (Barclay 1811). Many Scots, despite mounting evidence, largely promulgated by English (e.g. Home 1809), that the monster was nothing more than a decomposing basking shark (Swinney 1983), clung to their jingoistic belief otherwise throughout the nineteenth century (e.g. Traill 1854). Indeed, the Scottish islands are home to a long legacy of sea serpent/monster sightings (Harrison 2001), some, such as that of the "Soay Beast," being the subject of considerable speculation (Burton 1960, 1961; Brongersma 1968; France 2017).

The third facet of no surprise concerned the professional occupation of the authors of The Zoologist article. Just as nineteenthcentury alpinism was more-or-less the original purview of the clergy, even the most causal reading of scholarly compilations of sea serpent accounts (Oudemans 1892; Heuvelmans 1968; O'Neill 1999; Harrison 2001) reveals the prevalent role played by reverends, pastors, and ministers, on both sides of the Atlantic, in creating the phenomenon. Clergymen, well-educated, naturally inquisitive about elusive matters, and blessed with the luxury of considerable unstructured time, were always well represented in amateur naturalist groups throughout the 1800s. This was to be expected since, for many Victorians, the study of nature was invested with a theological significance. It is no coincidence that the 1789 classic of enduring popularity, which became the standard to be emulated by many, The Natural History of Selborne, was produced by a country parson, Gilbert White. Natural history had its roots in "natural theology," as popularized in William Paley's highly influential 1802 book, Natural Theology; or, Evidence of the Existence and Attributes of the Deity Collected from the Appearances of Nature. This work was based on the idea that there existed an overall design in nature, a rank and order in the great chain of life and regularity in the operation of laws, all of which being evidence of a transcendent guiding intelligence of a caring Creator (Berger 1983). For this reason, the practice of natural history was regarded as a morally uplifting enterprise that elevated the mind and expanded the heart (Barber 1980), making it an attractive and even ideal pastime for clergy. Furthermore, given the absence of a "smoking gun" in the form of a body (Shermer 2003), the acceptance of nineteenth-century testimonies concerning sea serpents depended much upon the societal position and consequent assumed character of eyewitnesses. Statements from gentlemen were accredited more than those from the working class, with a guaranteed verisimilitude should the eyewitnesses be men of God.

Contrary to all this expectation, what is so unusual about The Zoologist sea serpent account, enough so in this regard to surprise 
Victorian readers into suddenly sitting upright in their chairs and giving it their dedicated attention, is how markedly different the described circumstances were compared to the norm. Most sightings of sea serpents are extremely ephemeral affairs, lasting for a few minutes duration, and observed by only a few eyewitnesses. Someone shouts out excitedly to alert bystanders, and then, just as quickly as the mysterious UMO appeared, it is gone, never to be seen again, leaving the eyewitnesses to confirm, discuss, and debate about what they had collectively glimpsed. Even more common, however, is that most sightings have actually been made by solitary witnesses, with no one present to either corroborate or to discuss the encounter. In contrast, the case of the Leda UMO is extremely rare in the corpus of "seaserpentism" (sensu Mitchell 1829). The creature was observed in at least ten different locations and circumstances over a five-day period by more than a dozen individuals. In this regard, the Leda UMO is unique in the corpus of sea serpent sightings in the British Isles. It is impossible to simply dismiss the Leda UMO sightings as being hysteria of the type that gripped a very limited number of schoolgirls or nuns believing they had respectively seen either witches in Salem or devils in Loudun. Clearly the people in and around the Sound of Sleat did see something in the water, which appeared to them to be different from the norm, their confirmation bias kicking in to suggest it to have been a sea serpent. Finally, the events are described in such detail that, not without reason, did Paul Harrison label it the "most detailed account of a sea serpent encounter" in the British Isles (2001:153).

On the 20th of August 1872 we started from Gleneig in a small cutter, the

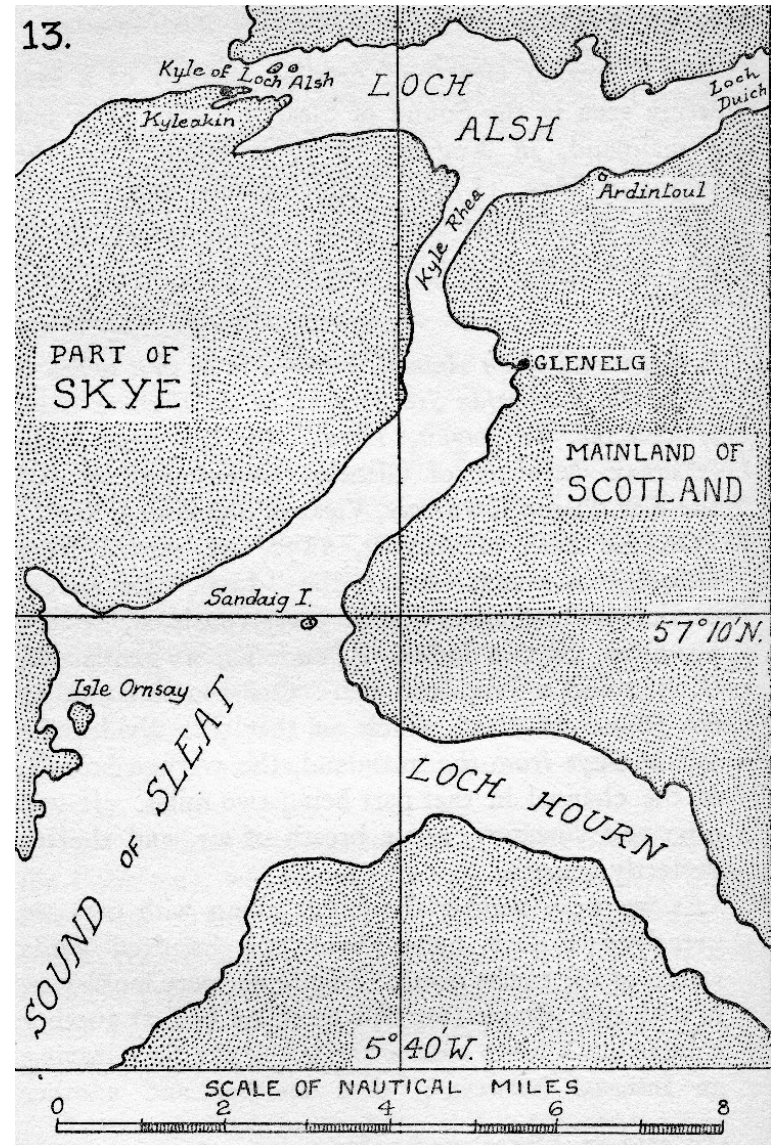

Figure 2. Area in the Scottish Hebrides where the Leda UMO was repeatedly seen by numerous eyewitnesses in August 1872. From Gould (1930).

Leda, for an excursion to Lochourn...Our course lay down the Sound of Sleat, which on that side divides the Isle of Skye from the mainland, the average breadth of the channel in that part being two miles [Figure 2].

It was a calm and sunshiny day, not a breath of air, and the sea perfectly smooth. As we were getting the cutter along with oars we perceived a dark mass about two hundred yards astern of us, to the north. While we were looking at it with our glasses...another similar black lump rose to the left of the first, leaving an interval between; then another and another followed, all in regular order. We did not doubt it being one living creature; it 
moved slowly across our wake and disappeared. Presently the first mass, which was evidently the head, reappeared, and was followed by the rising of the other black lumps, as before. Sometimes three appeared, sometimes four, five, or six, and then sank again. When they rose, the head appeared first, if it has been down, and the lumps rose after it in regular order, beginning always with the next to the head, and rising gently, but when they sank, they sank altogether rather abruptly, sometimes leaving the head visible. It gave the impression of a creature crooking up its back to sun itself. There was no appearance of undulation; when the lumps sank, other lumps did not rise in the interim between them. The greatest number we counted was seven, making eight with the head, as shown in sketch number one [Figure 3]. The parts were separated from each other by intervals of about their own length, the head being rather smaller and flatter than the rest, and the nose being slightly visible above the water; but we did not see the head raised above the surface either this or the next day nor could we see the eye. We had no means of measuring the length with any accuracy; but taking the distance from the centre of one lump to the centre of the next to be six feet, and it could scarcely be less, the whole length of the portion visible, including the intervals submerged, would be forty-five feet.

Presently, as we were watching the creature, it began to approach us rapidly, causing a great agitation in the sea. Nearly the whole of the body, if not all of it, had now disappeared and the head advanced at a great rate in the midst of a shower of fine spray, which was evidently raised in some way by the quick movement of the animal - it did not appear how - and not by spouting. Forbes was alarmed and retreated to the cabin, crying that the creatures were coming down upon us. When within about a hundred yards of us, it sank and moved away in the direction of Skye, just under the surface of the water, for we could trace its course by the waves it raised on the still sea to the distance of a mile or more. After this it continued at intervals to show itself, careering about at a distance, as long as we were in that part of the Sound; the head and a small part only of the body being visible on the surface, but we did not again, on that day see it so near nor so well as at first. At one time Forbes and Katie, and Gilbert Bogle saw a fin sticking up at a little distance back from the head, but neither of us were then observing.

On our return the next day we were again becalmed on the north side of Loch Hourn, where it is about three miles wide, the day warm and sunshiny as before. As we were dragging slowly along in the afternoon the creature again appeared over towards the south side, at a greater distance than we saw it the first day. It now showed itself in three or four rather long lines, as in sketch number two [Figure 3], and looked considerably longer than it did the day before; as nearly as we could compute, it looked at least sixty feet in length. Soon it began careering about, showing but a small part of itself, as on the day before, and appeared to be going up Loch Hourn, and when we had nearly reached the island of Sandaig, it came rushing past us about a hundred and fifty yards to the south, on its return from Loch Hourn. It went with great rapidity, its black head only visible through the clear sea, followed by a long trail of agitated water. As it shot along, the noise of its rush through the water could be distinctly heard 
on board. There were no organs of motion to be seen, nor was there any shower of spray as on he day before, but merely such a commotion in the sea as its quick passage might be expected to make. Its progress was equable and smooth, like that of a log towed rapidly. For the rest of the day, as we worked northwards through the Sound of Sleat, it was occasionally within sight of us till nightfall, rushing about at a distance, as before, and sowing only its head and small part of its body on the surface. It seemed on each day to keep pace about us and as we were always then rowing, we were inclined to think it perhaps might be attracted by the measured sound of the oars...We have only to add to this narrative of what we saw ourselves, the following instances of its being seen by other people, of the correctness of which we have no doubt.
The ferrymen on each side of Kylerhea saw it pass rapidly through on the evening of the 21st, and heard the rush of water; they were surprised, and thought it might be a shoal of porpoises, but could not comprehend their going so quickly. [Another individual]... with other men in his boat...saw the creature at about a distance of about one hundred and fifty yards. Two days after we saw it, [yet another individual]...was fishing in a boat in the entrance to Loch Duich...when he saw the animal, near enough to hear the noise, and see the ripples it made rushing along in the sea. He says that what seemed four or more humps, or "half rounds followed its head' as he calls them, and that they sometimes rose and sometimes sank altogether. He estimated its length at no less than between sixty and eighty feet. He saw it also on two

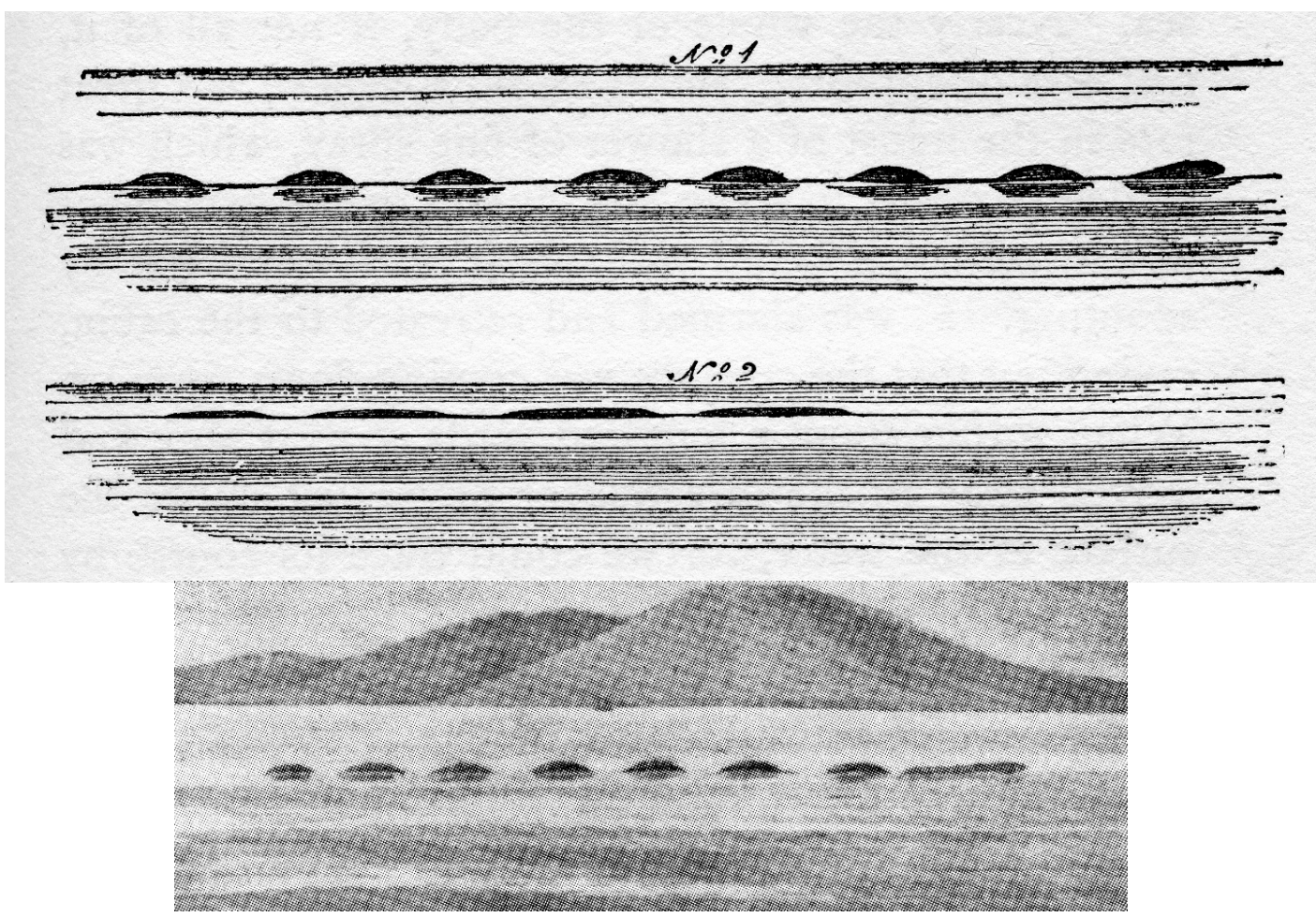

Figure 3. Subtle depictions of the many-humped Leda UMO, so unlike the often exaggerated illustrations of fantasy characteristic for the period. Upper couplet from Macrae and Twopeny (1873), and lower version from an 1872 article in Land and Water (in Heuvelmans 1968). Other eyewitnesses mention the presence of a dorsal fin sticking out above the surface. 
subsequent days in Loch Duich. On all these occasions his brother...was with him in the boat, and they were both much alarmed, and pulled to the shore in great haste.

A lady at Duisdale, in Skye, a place overlooking the part of the Sound...said that she was looking out with a glass when she saw a strange object in the sea, which appeared like eight seals in a row. This was just about the time that we saw it. We were also informed that about the same time it was seen from the island of Eigg, between Eigg and the mainland, about twenty miles to the southwest of the opening of Lochourn. We have not permission to mention the names in these last two instances.

\section{- John Macrae and David Twopeny}

\section{Reverend Twopeny adds a postscript:}

P.S. The writers of the above account scarcely expect the public to believe in the existence of the creature which they saw. Rather than that, they look for the disbelief and ridicule to which the subject always gives rise, partly on account of the animal having been pronounced to be a snake, without sufficient evidence, but principally because of exaggerations and fables with which the whole subject it beset. Nevertheless, they consider themselves bound to leave record of what they saw, in order that naturalists may receive it as a piece of evidence, or not, according to what they think it is worth. The animal will very likely turn up on those coasts again, and it will be in that 'dead season', so convenient to editors of newspapers, for it is never seen but in the still warm days of summer or early autumn. There is considerable probability that it has visited the same coasts before.

In the summer of 1871 , some large creature was seen for some time rushing about in Loch Duich, but it did not show itself sufficiently for anyone to ascertain what it was. Also, some years back, a well known gentleman of the west coast was crossing the Sound of Mull, from Mull to the mainland, on a very calm afternoon, 'When', as he writes, 'our attention was attracted to a monster which had to the surface, not more than fifty yards from out boat. It rose without causing the slightest disturbance of the sea, or making the slightest noise, and floated for some time on the surface, but without exhibiting its head or tail, showing only the ridge of the back, which was not that of a whale or any other sea animal that I had ever seen. The back appeared sharp and ridge-like, and in colour very dark, indeed black, or almost so. It rested quietly for a few minutes, and then dropped quietly down into the deep, without causing the slightest agitation. I should say that about forty feet of it, certainly no less, appeared on the surface'.

It should be noticed that the inhabitants of the western coast are quite familiar with the appearance of whales, seals, and porpoises, and when they see them they recognize them at once. Whether the creature which pursued $\mathrm{Mr}$ M'Clean's boat off the island of Coll in 1808 and of which there is an account [published]...was one of these Norwegian animals, it is not easy to say. Survivors who knew Mr McLean say he could quite be relied upon for the truth. The public are not likely to believe in the creature until it is caught, and that does not seem likely to happen just yet, for a variety of reasons. 
One reason being that it has, from all accounts given of it, the power of moving very rapidly. On the $20^{\text {th }}$, while we were becalmed in the mouth of Loch Hourn, a steam launch slowly passed us, and, we watched it, we reckoned its rate at five to six miles an hour. When the animal rushed past us on the next day at about the same distance, and when we were again becalmed nearly in the same place, we agreed that it went twice as fast as the steamer, and we thought its rate could not be less than ten or twelve miles an hour. It might be shot, but would probably sink...

It should be mentioned that when we saw this creature, and made our sketches of it, we had never seen either Pontopiddan's Natural History or his print of the Norwegian evidence, extending through a number of years, which remains after setting aside fables and exaggerations. It seems surprising that no naturalist has ever applied himself to make something about the animal. In the meantime, as the public will most probably be dubious about quickly giving credit to our account, the following explanations are open to them, all of which have been proposed by me, viz: porpoises, lumps of seaweed, empty herring barrels, bladders, logs of wood, waves of sea, and inflated pig-skins! But as all these theories present to our mind greater difficulties than the existence of the animal itself, we feel obliged to decline them.

Further Details from Eyewitnesses, and Historiography of Subsequent Cryptozoological Interpretations

Compared to the flurry of commentary arising from sightings of other, more famous, UMOs, such as that of Egede monster of 1734, the Gloucester and Boston craze of
1817-19, and the Daedalus sea serpent of 1848, the Leda encounter has received little attention, both at the time and ever since.

Edward Newman, editor of The Zoologist, used his prerogative and commented directly following the letter, in which he emphasised his belief in the veracity of the account and illustration as they did not stray into the dubious territory of exaggeration:

I have long expressed my firm conviction that there exists a large marine animal unknown to us naturalists: I maintain this belief as firmly as ever. I totally reject evidence of published representations; but I do not allow these imaginary figures to interfere with a firm conviction, although I admit their tendency in that direction: the figures and exaggerated descriptions of believers are far more damaging to a faith in such an animal than the arguments, the ridicule, or the explanatory guesses of unbelievers. The guess that a little seal was magnified by Captain M'Quhae [of the H.M.S. Daedalus and eyewitness to the famous 1848 sighting of an UMO] into a monster several hundred feet in length is simply incredible: we smile at the conceit, and that is all.

Antoon Oudemans, in his comprehensive The Great Sea-Serpent of 1892, devotes a paragraph to the incident. Herein, he equates the Leda creature with others seen in Norway, Massachusetts, as well as Scotland (see next section). He is content to present the Leda sightings as simply four more sea serpent reports (Nos. 137 to 140) to add to his diachronic tally.

Sea Monsters Unmasked by Henry Lee (1883) is notable for being an early attempt to explain what have since become known as "cryptids," or hidden animals, by known zoological explanations. His commentary 
about the Leda UMO is brief: "A sketch of it was given which almost exactly accorded with that of Pontopiddian's sea serpent, namely, seven hunches or protuberances like so many porpoises swimming in a line, preceded by a head and neck raised slightly out of water" (p. 140). He goes on to refer to the encounter, almost dismissively, as just another of the many such that have suggested the appearance of serpent-like sea monsters. Elsewhere in his book, he makes a case (it must be said, not terribly convincingly) that most of these can be ascribed to various configurations of the tentacles of giant squid, the "kraken" of lore.

In The Case for the Sea-Serpent (1930), R.T. Gould, like Oudemans before him, presents both the entire text and postscript of the Reverends Macrae and Twopeny's original letter and illustrations from The Zoologist, as well as providing a map of the sighting locations (Figure 1). He also shows extracts from an earlier account published in 1872 in the popular magazine Land and Water. Emphasised herein is mention that the tremendous rush or tumult of water at the eyeless-mouthless-flattish head of the UMO, audible enough to be heard on board the boat and even by spectators on the shore, might have been "caused by a mane lashing about." In this 1872 account, Reverend Twopeny describes seeing "the sea running off its back and the back of its head, as it does from a low flat rock which has been submerged by a wave" (p. 150). The six-to-eight counted humps, appearing as "dark ridges" which did not at all look like waves, were noted to rise sequentially, one after the other, "easily, and not without a jerk." Gould tangentially notes that several other sightings were reported in the area around the same time as that of the Leda but does not offer any personal commentary on the nature of the beast; it is simply one more of the many mysterious monsters that reside, unexplained, beneath the waves.

Bernard Heuvelmans, in his 1968 In the Wake of Sea-Serpents - the book that more than any other initiated the modern pseudoscience of cryptozoology-prefaces the Leda account by noting that with this particular sighting by "very respectable witnesses" (p. 254) was of historic significance since it showed the irrefutable presence of such creatures in a place where their existence had been seriously questioned ever since the 1808 misidentification of a decomposing basking shark as the Stronsay Beast. Importantly, two other snippets of details from other eyewitnesses are provided concerning the observed fins (letter from Ms. Macrae to Oudemans, and letter from Bogle in the Newcastle Weekly Chronicle of 1877 , both in Heuvelmans 1968:255):

'In a few minutes afterwards,' wrote Miss Katie Macrae, 'the row of lumps appeared again about a mile behind, and this time a triangular fin stuck up from about the 4th lump, and apparently $10 \mathrm{ft}$., the size of our jib.' Gilbert Bogle says 'I distinctly saw the colour of the creature, and what appeared to be a small fin on the back or neck, moving rapidly sideways, and two or three yards behind he head. Its colour was a dark slaty brown, somewhat similar to that of a porpoise.'

To which Heuvelmans adds his contention that the two individuals were referring to two different kinds of fin. He then returns to quoting the Land and Water article, in which Reverend Twopeny states that the appearance and propulsion of the UMO was unlike "any known cetacean, shark, or fish of any kind."

Heuvelmans also includes an excerpt from an 1873 letter to The Times by the fisheries zoologist and natural historian, Dr. 
Frank Buckland, entitled "The Scotch Sea Snake." A frequent commentator on sea serpent sightings from around the world, here Buckland backs away from his previous supposed candidate identity of a giant conger eel, and suggests that it might have been an oarfish that the Leda witnesses observed. But that said, he rightly points out that the illustrations indicate vertical curvature, something not possible for most fish which propel themselves through sideways flexure...unless, however, the candidate might be some form of flatfish (as for example a halibut) which has reorientated itself onto one side...or perhaps an intoxicated or partially paralysed oarfish swimming on its side. Heuvelmans considers such suggestions as unlikely candidates to explain the animal seen by the Leda. Rightly he notes that Macrae and Twopeny specifically stated that "there was no appearance of undulation." From this he logically concludes that, just as for the case of the American sea serpent (by this he means the UMO seen around Gloucester, Massachusetts in 1817-19), that "the supposed vertical undulations may be due to the sea-serpent's anatomy rather than its motion" (p. 257). For Heuvelmans, the Leda UMO is a classic example of his "manyhumped" sea serpent category.

Sweeney (1972) paraphrases the account but does not show the illustrations. Harrison (2001) includes the entire The Zoologist transcription, but also omits the illustrations. Neither author offers any opinions. McEwan (1978) provides a truncated version of the encounter which he prefaces by stating that, unlike some hoaxes, the Leda incident, because it is described "with obvious restraint and objectivity," "cannot be dismissed so contemptuously" (p. 24). He shows his own rendition of one of the illustrations. The Leda UMO is absent from other modern books (Ellis 1994; Coleman and Hughe 2003; Woodley 2008; Paxton and Lothero 2015).

\section{RESULTS AND DISCUSSION}

\section{New Parsimonious Conservation Biology Illation}

The most notable behavioral feature of the Leda UMO was its occasional rapid speed of movement which caused a disturbance considerable enough to produce a "shower of spray" audible from a distance. Perplexingly, propulsion was caused by neither undulations of its elongated "body," nor by any distal or caudal forces. Sometimes the entire bulk of the UMO was seen to be pulled downward, one "black lump" after another quickly disappearing into the depths with little or no warning. When one lump disappeared under the surface, there was no progressive undulation in which successive humps filled the space between them, before each in turn was lost to sight. Upon resurfacing, the opposite would happen, with each integral lump bobbing up in sequence. At other times, the UMO was seen hardly moving or perhaps motionless upon the water, the elements comprising the body extended above the surface as if the animal was basking in the sun. Intriguingly, the portion of the UMO observed above the surface appeared to neither take notice nor be nervous of approaching the various water craft. Something in the water was obviously of attraction to keep the UMO in the same general area, "careering about," for five days. Sightings of similar UMOs in the region are noted to be restricted to the summer and early autumn.

The most notable anatomical feature of the Leda UMO was that its considerable, 45 
to 60-foot, length was made up of a series component body parts, including the premier one which was assumed to be the head. These so-called dorsal "lumps" were described from an earlier sighting as being "sharp and ridge-like," and separated by intervals. This distinctive structural form was maintained even while the irregular body parts "floated" on the surface when the UMO was not in rapid motion. Remarkably, the UMO was observed to have neither discernable tail fins nor any lateral appendages which might account for its propulsion. Several eyewitnesses, however, describe the presence of a dorsal fin rising above the surface.

Reverend Twopeny, in his Postscript, briefly considers alternative hypotheses for the observed UMO: three are biologicallybased (porpoises, seaweed lumps, and logs), one aqueous (waves), and three anthropogenic (empty herring barrels, bladders, inflated pig-skins), all of which seem to him to be unlikely compared to the UMO being a single, live animal. He then briefly gives his two cents worth by likening the creature to resembling the famous sea serpent described by Pontopiddian (1755), but is emphatic that he cannot, as others have cavalierly done in the past, pronounce it to be a true snake. Oddly, he makes the following statement, in ignorance of the copious literature to the contrary, that "it seems surprising that no naturalist has ever applied himself to make something about the animal [i.e. the sea serpent]." This gives credence to his statement that the eyewitness descriptions and illustrations were made independent of knowing about Pontopiddian's dominating influence on all such matters throughout the nineteenth century.

There are very few marine animals of the reported size of the Leda UMO, and none of them have narrow bodies that resemble the Scottish creature as so described. The body form of aquatic animals is such that they are designed to move through the water as effortlessly as possible. The tumultuous spray of water displayed is therefore unnatural and a clue that something else is going on here that is non-biological in origin. As is the rigid composition of the UMO's dorsal protuberances, each separated invariably from the next in the line, rising and falling in sequence when the animal submerges or resurfaces. And then there is the mysterious force behind the UMO's locomotion, a puzzle to explain given the absence of tail flukes, fins, and side-to-side undulations. In short, the animal's movement is a biomechanical impossibility.

There is really only a single explanation for the Leda UMO. I believe that Reverend Twopeny comes closest to the truth when he writes that the physical and behavioral characteristics of the body were "like that of a log towed rapidly." The parsimonious (i.e. al à Occam's razor) and noncryptozoological explanation behind the Leda UMO is that it was an animal observed pulling a string of fishing net or harpoon-line floats in which it had become either nonlethally entangled or possibly struck and affixed. Twopeny's postulation of alternative theories for the imagined sea serpent is stymied by an inability to countenance that a train of "empty herring barrels, bladders...and inflated pig-skins"-all of which were used, in addition to pieces of cork and blown-glass balls (see contemporaneous illustrations from Goode et al. 1884 and photographs of artifacts from maritime museums in France 2016,a,b, 2017,2019 ), as fishing net or harpoon-line floats in the nineteenth century-would display mobility like the observed UMO in consequence of their being attached to an 
animal.

The abundance and biodiversity of more than two hundred species of marine animals, including many species of sharks, are affected by the serious problem of entanglement in marine debris and fishing gear (Laist 1997; Derraik 2002). Whereas it is true that earlier nets and ropes made from natural hemp fibre (Figure 4) will have deteriorated more rapidly compared to modern nylon or polyethylene ones, it would be erroneous to suppose, as have others (e.g. Gregory 2009; NOAA 2014; Vegter et al. 2014), that such material, in order to be of sufficient durability for their continued widespread maritime use (Aiken and Purser 1936; McCaskil 2009), would not have lasted long enough to pose a threat for entangling susceptible wildlife (Deedy 2017). Furthermore, during the nineteenth century, hemp ropes were often impregnated with dye or pine tar as a mordant to extend their longevity (Kristjonsson 1971; Bekker-Nielsen and Casola 2001) or were even reinforced with braided wire (Goode et al. 1884).

Some animals can remain non-lethally entangled in fishing gear or maritime debris for extended periods of months and even years (Johnson 2005; Fama 2012), as for example, a recent case in Scotland (Anon. 2019a). Entangled animals can travel thousands of kilometres (Lyman in NOAA 2014). For example, the carcass of a juvenile humpback whale, which was discovered on a beach in northern Scotland, not too far from where the Leda UMO sighting took place 147 years ago, was found to be entangled in the line and float of a lobster trap from Nova Scotia, the poor individual having survived long enough to pull the cumbersome fishing gear a distance of more than four thousand kilometres before succumbing (Anon. 2019b). Sadly, this animal also displayed scars from a previous, in that case, non-lethal, entanglement. In the past, before the use of synthetic lines, the opportunity for an entangled animal to escape would have been much greater. Animals could often muscle their way through gill nets made of cotton or flax twine and hemp, sometimes in the process making off with portions of the net and its accompanying floats in tow. Nonlethal entanglement in the nineteenth century may have lasted, if not for half a decade or longer as today due to nondegradable plastic, at least for a duration of months, and possibly several years. This would certainly have been sufficient time for an unfortunately entangled animal pulling a string of buoys through the water to easily be misconstrued as a sea serpent (contemporaneous illustrations of strings of fishing net floats from Goode et al. 1884 that resemble the "lumps" of the Leda sea serpent are shown in France 2016a,b, 2017, 2018, 2019).

In his comprehensive overview of late nineteenth-century fishing in the British Isles, Wilcocks (1884) describes and illustrates many methods in use at the time (Figure 4). Additionally, with respect to northern Ireland, north-west Scotland, and the coast of Norway, nets were purposely set to entrap basking sharks during the nineteenth century (Fairfax 1998; Speedie 2017). In short, already by the time of the Leda incident, an obstacle course of deployed fishing gear existed along the northeast Atlantic coast in which to permanently entrap or temporarily entangle marine animals. Furthermore, commercial fisheries also existed in the northern Atlantic that involved hunting cetaceans and basking sharks with thrown harpoons (Fairfax 1998; Szabo 2008). In a procedure referred to as "kegging," basking shark, giant Bluefin tuna, and whale fishermen would attach a string of buoys, 
30 thread

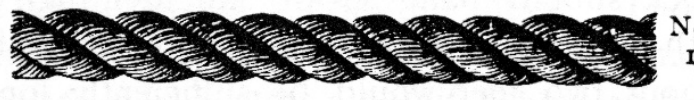

15 do.

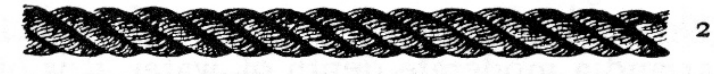

12 do.

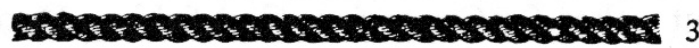

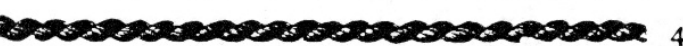
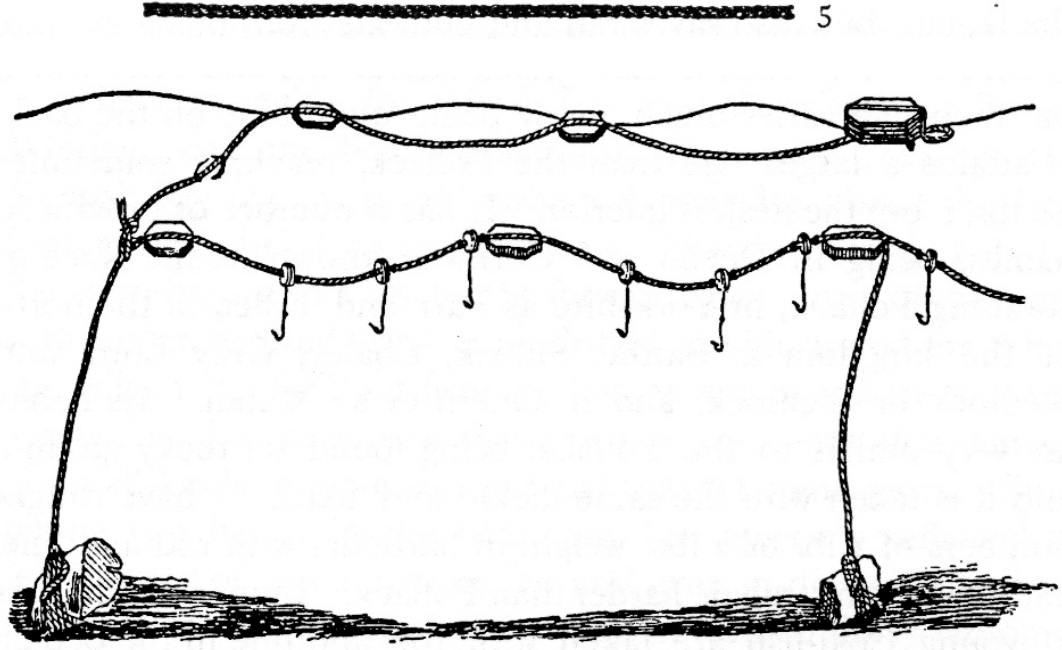
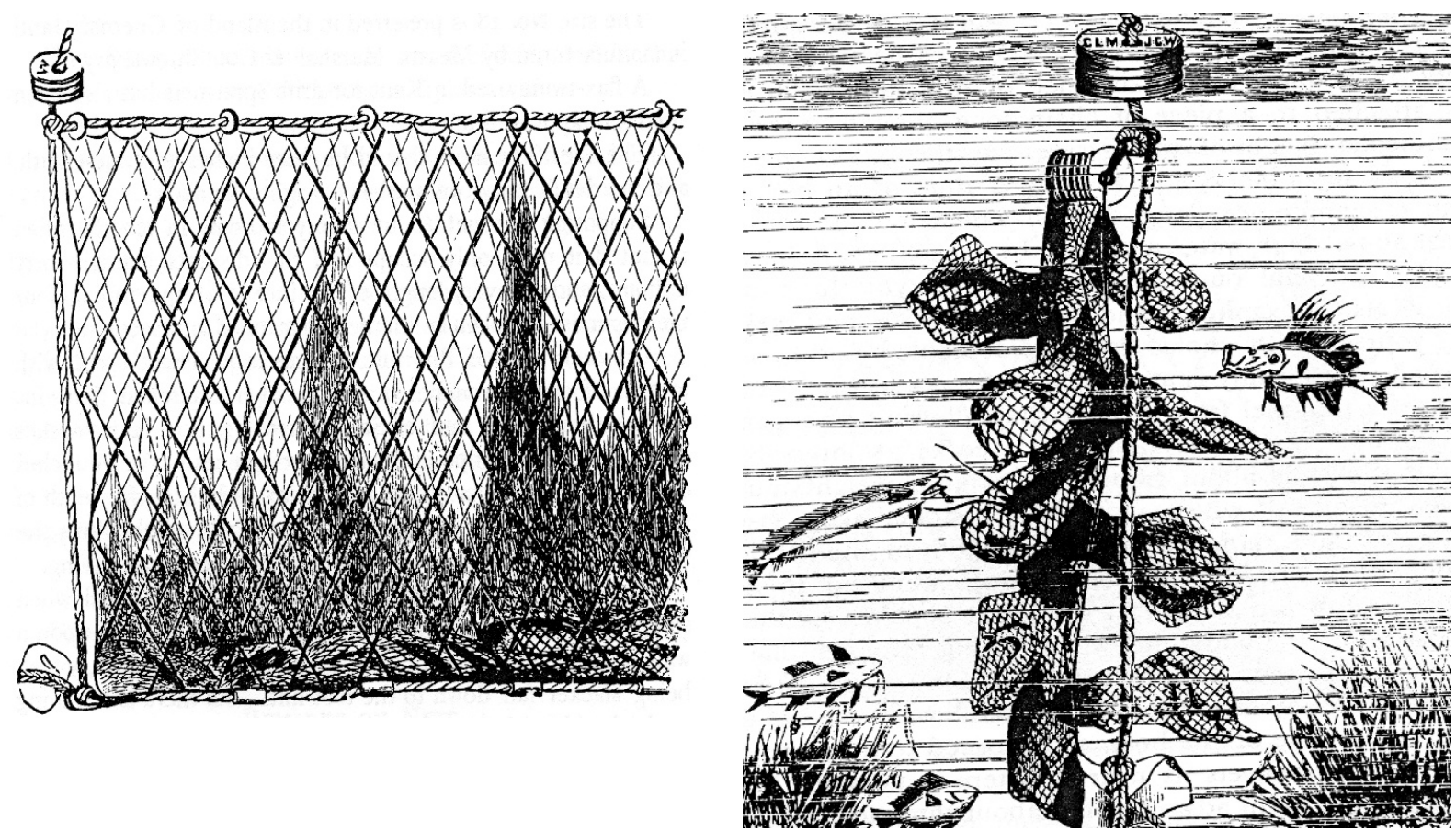

Figure 4. Fishing gear composed of natural material - hemp cordage, flax-twine mesh netting, and cork floats - used in the British Isles in the late nineteenth century, and all posing a threat for entangling basking sharks and other marine life. From Wilcocks (1884). 
barrels, or drums to the harpoon line in attempt to create enough resistance to slow animals down (photographs of such artifacts from various maritime museums are shown in France 2019). Some of these struck creatures could have survived for extended periods (Gardner 2007). Indeed, in preballistic times, it is thought that up to a quarter of all struck whales actually managed to evade capture (Mowat 1997). For example, the famous polar explorer Fridtjof Nansen recounts (in France 2019) losing equipment to one such animal that escaped from him, not once, but twice. One wonders if the next person who spotted Nansen's struck whale, pulling along its three intertwined ropes and series of caskfloats behind, perhaps festooned with kelp strands or other maritime debris, imagined that $s /$ he had caught a glimpse of the elusive sea serpent.

\section{Examination of Evidentiary Support and Refutation in an Imagined Moot Case}

The nineteenth century was a time of considerable zoological debate concerning the relationships between living species known to Europe and those new ones being discovered from both the far-flung corners of the increasingly explored world, as well as from fossils excavated from the rock strata of deep time. How to contribute to and then classify this rapidly increasing biodiversity became a major preoccupation of naturalists, both professional and avocational. Taxonomic boundaries were often blurred (Ritvo 1997, 2010); no more so than in reference both to whales (Guizard 2018), which had a long history of being regarded as monsters (Hendrikx 2018), as well as imagined-to-be real monsters such as sea serpents, which may or may not be giant aquatic snakes (Lyons 2009), about which some mystery existed (Svanberg 1999).

Often the debate assumed a stylized legalistic form. Most notably in this regard was the famous court case in New York City wherein it was proven that whales were not in fact mammals but rather fish (Burnett 2010). Next to clergymen and physicians, the membership of many amateur naturalist societies was composed of judges and lawyers. In consequence, and given the controversial acceptance for the existence of sea serpents, the first thing that many eyewitnesses did upon debarking ship after having seen an UMO on their voyage, was to report to the nearest dock-side legal office to file notarized testimony, sworn to by themselves and as many supporting crew or passenger eyewitnesses as possible. In the cases where naturalists delved deeply into notable sightings, their resulting writings were often presented with a statement or seal of legal authority (e.g. Davis et al. 1817). In ongoing debates about the true nature behind famous sea serpents, such as the Stronsay carcass of 1808 (Swinney 1983) or the Daedalus UMO of 1848 (Regal 2012), which raged in learned journals and the popular press, sometimes for decades, often these exchanges mimicked the evidentiary format of a trial. And when sea serpent believers commented upon the latest reported sighting, almost invariably they would in legalistic style, just as did Reverends Macrae and Twopeny, make reference to earlier sightings as a way to shore up their suppositions by demonstrating the long precedence for the existence of such animals. Antoon Oudemans, in his seminal 1892 compendium The Great SeaSerpent, for example, provides evidence which he believes to be of confirmatory support for the Leda sea serpent by referring 
to previously observed and famous sea serpents in Norway and Massachusetts, as well as to a less well-known one from the Scottish Isles. In the next section, I will, Agent Mulder-like ${ }^{1}$ present this "the truth is out there" cryptozoological evidence, critically comment upon it, and then, Agent Scully-like ${ }^{2}$ present alternative conservation biology evidence from the same regions which suggests that "sea serpents" there, as I believe to be the case for the Leda UMO in the Sound of Sleat, are all mundane animals observed in the state of misfortune of pulling trains of entangled fishing nets, hunting gear, or other maritime debris.

1. For his Norwegian cryptozoology point using confirmatory expert and witness evidence, Oudemans (1892) first draws readers' attention to the fact that the illustrations of the Leda encounter are nearly exactly the same as those in the drawing produced by Mr. Benstrup, as described in Bishop Pontopiddian's 1755 classic The Natural History of Norway. A standard in all nineteenth-century naturalists' libraries, this widely read and influential book can be said to have initiated the modern sea serpent phenomenon (Gould 1930). According to Lee (1883), the drawing (Figure 5) was produced by another clergyman and is a representation of the UMOs observed in 1746 and 1747 by both Governor Benstrup and Royal Commander Lorenz von Ferry, the pilot-general at Bergen. Oudemans' commentary on the illustration is that it shows a distinct head with a large eye, a nostril, but no teeth. Behind this trails a shoulder-length mane and a sinuous body composed of six large "coils." von Ferry provided the following testimony to legal authorities, which was subsequently sworn to by ten corroborating witnesses (Oudemans 1892:104):

I was informed that there was a sea- serpent before us; I then ordered the man at the helm to keep the land again, and to come up with this creature of which I had heard so many stories. Though the fellows were under some apprehension, they were obliged to obey my orders. In the meantime, the sea-snake passed us by, and we were obliged to tack the vessel to get nearer to it. As the snake swam faster than we could row, I took my gun which was loaded with small shot, and fired at it; on this he immediately plunged under water. We rowed to the place where it sank down...and lay upon our oars, thinking it would come up again to the surface; however it did not. Where the snake plunged down, the water appeared thick and red; perhaps the small shot might have wounded it, the distance being very little. The head of this sea-serpent, which it held more than two feet above the surface of the water, resembled that of a horse. It was of a greyish colour and the mouth was quite black and very large. It had black eyes, and a long white mane, which hung down from the neck to the surface of the water. Besides the head and neck, we saw seven or eight folds, or coils, of this snake, which were very thick, and as far as we could guess there was a fathom's distance [i.e. about two metres] between each fold.

Oudemans makes much ado about the colouration of the creature's head, noting that such sea serpents have skin like that of pinnipeds (seals and sea lions). He then runs off into the kind of Kiplingesque "justso" story-telling that often categorizes cryptozoology by speculating that the reason why von Ferry found the skin on the head to be grey rather than its normal hue of dark brown was due to the weather being hot that day and the skin drying out just as one can see when observing sea-lions on beaches. 


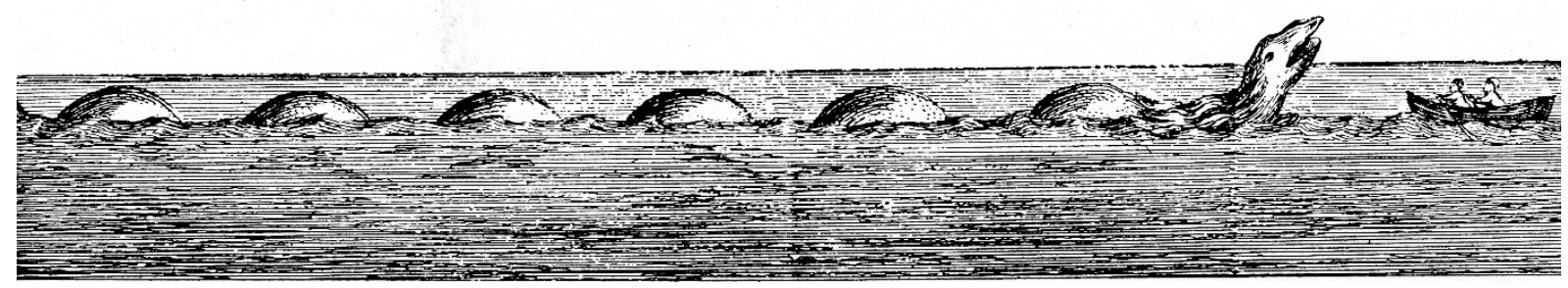

Figure 5. The many-humped Norwegian sea-orm from Pontopiddian (1755), which was referred to by Macrae and Twopeny in the title of their 1873 letter published in The Zoologist about the Leda UMO, and used by Oudemans (1892) as evidentiary support for the existence of sea serpents, including the one seen by those aboard the Leda.

He then cites a scientific letter by Harvard professor William Peck whom, though the naturalist considered the existence of the sea serpent to be "sufficiently conclusive," thought that the mane was merely an optical deception caused by spray as the animal moved forward. Lee (1883) explained the "supposed coils" here and in all such accounts as being nothing more than a series of porpoises following each other in a line, as is their common practise. He also notes that anatomical impossibility of any snake throwing its body into such vertical undulations. Oudemans dismisses these criticisms: Peck is wrong as he had been biased by the fact that none of the eyewitnesses of the Gloucester Sea Serpent had observed the presence of a mane (elsewhere, he explains the difference due to sexual dimorphism between the particular individual American and Norwegian sea serpents being sighted); and Lee is wrong as he is silent with regard the head of the creature, only noting that it did not resemble that of a snake. "A fine explanation indeed!", Oudemans comments snidely.

2. For my Norwegian conservation biology counterpoint using alternative expert and witness evidence, I note that despite Oudemans' attempt to link the Leda UMO to the earlier famous sightings compiled by Pontopiddian, even the briefest perusal of the illustrations indicates that there are obvious differences. The Scottish creature displays neither an elevated, horse-like head, nor a mane. Where the illustrations and accounts do match is in the interspersed series of humps or coils that were observed above the surface of the water. This is the characteristic trait of the so-called "manyhumped sea serpent," one of the most prevalent typologies, and one which is believed by cryptozoologists to have a "marked predilection" for Massachusetts (see below) and north-west Scotland (Heuvelmans 1968).

It is my parsimonious contention that all such many-humped UMOs are merely animals with the misfortune of being nonlethally entangled in fishing nets, hunting equipment, or other maritime debris. The occasionally remarked-upon presence of a hairy "mane" draped about the neck or back is suggestive of enveloping mesh netting. Strings of floats dragged along the surface behind can explain "humps" or "coils" (France 2016a,b, 2017, 2018). Even Bishop Pontopiddian (1755) himself acknowledged the likeness of UMOs to such, as witness to his own summarizing observations about 
sea serpents, in which he notes that though once doubting in their existence, he became a believer due to the "incontestable proof":

Though no one has ever been able to measure this animal, many witnesses agree that the serpent must be as long as a cable, viz., 100 fathoms or 300 ells [180 metres], whilst it lay on the surface of the water, so that only here and there behind the head, which is held upwards, some parts of the back were visible, which were also held upwards, whilst the serpent bent; and from afar one would have believed that he saw some tuns or hogsheads [i.e. different sized barrels], which floated in a line, so that there was a space between each of them.

Generally, things which are thought to resemble a floating line of barrels are more than likely to really be a floating line of barrels (Loxton and Prothero 2015). This is the "duck test" of abductive reasoning (i.e. if it looks, swims, and sounds like a duck, then it probably is a duck). Although Oudemans (1892) comments on the remarkable repetition of eyewitnesses each independently describing the bodies of UMOs as resembling a line of floating barrels, his confirmation bias stops short of allowing him to follow Occam's Razor to its obvious conclusion. The same pertains for Heuvelmans (1968), whom even goes as far as to frequently refer to his many-humped category of UMOs with the sobriquet of "string of buoys."

3. For his Massachusetts cryptozoology point using confirmatory expert and witness evidence, Oudemans (1892:249) next reminds readers of the similarity between descriptions of the disappearing and reappearing behavior the Leda UMO and that of American reports of the Gloucester Sea Serpent "sinking down like a rock." The Gloucester Sea Serpent remains the most sighted and studied sea serpent in history. Of the nearly ninety documented eyewitness accounts (Davis et al. 1817; Sargent 1818; Soini 2010), one of the most detailed ones comes from James Prince who, along with several hundred others, observed the UMO in Boston Harbour in the summer of 1819 (France 2019:126):

I presume I may have seen what is generally thought to be the seaserpent... On our arrival on the beach, we associated with a considerable number of persons, on foot and in chaises, and very soon an animal of the fish-kind made his appearance. His head appeared about three feet out of water; I counted thirteen bunches on his back: my family thought there were fifteen-he passed three times at a moderate rate across the bay, but so fleet as to occasion a foam in the water-and my family and myself, who were in carriage, judged he was fifty feet in length, and, at the extend, not more than sixty; whether, however, the wake might not add to the appearance of his length; or whether the undulation of the water, or his peculiar manner of propelling himself, might not cause the appearance of protuberances, I leave for your better judgment...

As he swam up the bay, we and the other spectators moved on, and kept abreast of him; he occasionally withdrew himself under water, and the idea occurred to me that this occasionally raising his head above the level of the water, was to take breath, as the time he kept under water was of an average about eight minutes; after being accustomed to view him, we became more composed; and made the annexed figure of his outlines [Figure 6]...

After being on the long beach about an hour [and observing him], the animal 
disappeared...[While on another nearby beach] we had more than a dozen different views of him, and each similar to the other...l feel satisfied of the correctness of my decision that he is sixty feet long, unless the ripple of his wake deceived me-nor my dear sir, do I undertake to say he was of the snake or eel kind, though that was the general impression on my family, the spectators and myself. Certainly it is a very strange animal.

The role of the Gloucester Sea Serpent in the antebellum development of the culture and science of American natural history was profound (Brown 1990; Burns 2014; France 2019), as has been its continued influence on the pseudoscience of cryptozoology ever since (France 2019), wherein it is touted as being "by far the best-documented evidence that sea-serpents exist" (Bauer 2013). Oudemans (1892), for example, devotes considerable space to interpreting the Gloucester UMO, noting the creature's multiple "coils, or joints, or bunches" were evident even when the animal was at rest and cannot be explained away as being due to rapid motion. He cherry-picks particular anecdotes to support his pet-theory that all sea serpents are a single type of prehistoric marine mammal, ignores conflicting evidence suggesting otherwise, and remarkably even goes as far as to invent what he believes the eyewitnesses truly saw, irrespective of what they actually reported to having seen. Further interpretations, many blinkered by overt confirmation bias, from later cryptozoologists, are presented in France (2019).

4. For my Massachusetts conservation biology counterpoint using alternative expert and witness evidence, I note that if the elevated "head" is removed from Prince's Massachusetts illustration, one can certainly see the similarity between it and the Leda UMO. In point of fact, most of the eyewitnesses of the Gloucester UMO did not report seeing any head. For those that did, the "head" appeared to be devoid of physical characteristics that one would expect. For example, my selected counterpoint anecdote from 1815, wherein Elkanah Finney spotted a strange creature in the Bay State waters, is a teaser for what would become commonplace observance by hundreds of gaggling onlookers two years hence (France 2019:108):

I looked towards the cove, where I saw something which appeared to the naked eye to be a drift sea-weed. I then viewed it through a perspective glass, and was in a moment satisfied that it was some aquatic animal, with the form, motion, and appearance of which I had hitherto been unacquainted. It was about a quarter of a mile from the shore, and was moving with great rapidity...The animal went about a quarter of a mile to the northward; then turned about, and while turning, displayed a greater length than I

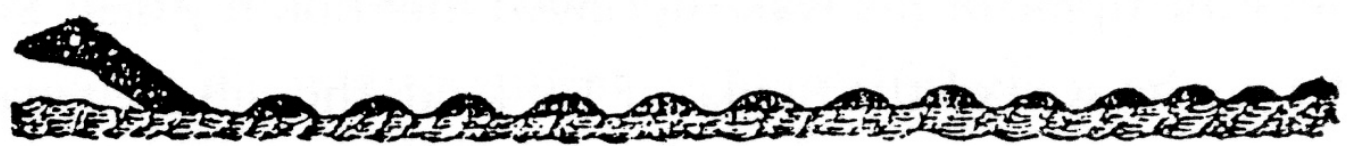

Figure 6. Illustration by James Prince of the many-humped Gloucester Sea Serpent, referred to by Oudemans (1892) as evidentiary support for the existence of sea serpents, including the one seen by those aboard the Leda, and alternatively by France (2019) to suggest that the UMO to have been an entangled animal. 
before seen; I supposed at length a hundred feet. It then came towards me, in a southerly direction, very rapidly, until he was I line with me, when he stopped, and lay entirely still on the surface of the water. I then had a good view of him through my glass, at the distance of a quarter of a mile. His appearance in this situation was like a string of buoys. I saw perhaps thirty or forty of those protuberances or bunches, which were about the size of a barrel. The head appeared to be about six or eight feet long, and where it was connected with the body was a little larger than the body...I could not discern any mouth...While he lay in this situation he appeared to be about a hundred or a hundred and twenty feet long. The body appeared to be of a uniform size. I saw no part of the animal which I supposed to be a tail...l could not discover any eyes, mane, gills, or breathing holes. I did not see any fins or legs. The animal did not utter any sound, and did not appear to notice any thing. It remained still and motionless for five minutes or more... The next morning I rose very early to discover him...He often disappeared, and was gone for five or ten minutes under the water. I thought he was diving or fishing for his food...His quickest motion was very rapid: I should suppose at the rate of fifteen or twenty miles an hour. Mackerel, menhaden, herring, and other bait fish abound in the cove where the animal was seen.

The absence of a distinctive head, tail, and fins in this anecdote, as well as likening the series of numerous body protuberances to resembling "a string of buoys," bespeaks of a train of floats from a fishing net. More than a dozen other eyewitnesses (France 2019) describe the UMO's body similarly: "like the buoys of a net," "joints like wooden buoys on a net rope," "like a string of empty barrels tied together," "like a string of kegs connected on a rope," etc. Despite the obvious parsimonious illation, Heuvelmans (1968), in In the Wake of the Sea-Serpents posits his own theories to explain what he refers to as "the appearance of a string of buoys" (my italics): vertical bends in a very long animal, a row of solid dorsal humps or air-filled sacs, transverse folds or perhaps turbulence waves in a very fat body (i.e. there is no end to the imagination that cryptozoologists sometimes invoke to avoid the obvious). It is also worth noting that Finney's 120-foot estimated length for his sighted UMO is non-tenable given that there has never existed any marine animal larger than the present-day 30-metre (98-foot) Blue whale. Only a non-biological explanation such as a true "string of buoys" can account for such an enormous length, something given additional credence by the imperviousness of the "body" of the Gloucester UMO to barrages of musket shot, and even in one case, remarkably, cannon fire.

And with respect to those few eyewitnesses of the Gloucester UMO who did observe a head, I agree with Fama's (2012) interpretation that the first keg or buoy in the line must have been different than the others (e.g. the presence of what I believe to have been a marlinspike that was likened by some to being the serpent's tongue - France 2019), thereby creating the illusion of a head raised above the body. The rapid disappearance and reappearance singled out by Oudemans as linking the comparative behaviors of Leda and Gloucester UMOs is an important point. The description in Finney's anecdote (as well as those of others) of the train of float-like humps lying motionless upon the surface for extended periods, followed by their sudden 
downward disappearance, together with the absence of any head noted by most eyewitnesses, led me to posit that the entangled animal behind the Gloucester UMO was not an air-breathing whale as Fama (2012) had proposed, but rather, as I believe to also be the case for the Leda UMO, a large fish (France 2019).

5. Finally, for his Scottish Isles cryptozoology point using confirmatory expert and witness evidence, Oudemans, following the lead of Reverends Macrae and Twopeny, emphases the historical precedence of a pair of sea serpent sightings from 1808 that took place in the same locality. At a meeting of the Wernerian Natural History Society on the $13^{\text {th }}$ of May 1809 , the Secretary read a letter by member Reverend Donald Maclean concerning a large UMO which had been seen in the Hebrides the preceding June (in Oudemans 1892:125):

I observed [off the coast of Coll], at about a distance of half a mile, an object to windward, which gradually excited astonishment. At first view it appeared like a small rock. Knowing there was no rock in that situation, I fixed my eyes on it close. Then I saw it elevated considerably above the level of the sea, and after a slow movement, distinctly perceived one of its eyes. Alarmed at the unusual appearance and magnitude of the animal, I steered so as to be at no great distance from the shore. When nearly in a line betwixt it and the shore, the monster directing its head (which still continued above water) towards us, plunged violently under water. Certain that he was in chase of us, we plied hard to get ashore. Just as we leaped out on a rock, taking a station as high as we conveniently could, we saw it coming rapidly under water towards the stern of our boat. When within a few yards of the boat, finding the water shallow, it raised its monstrous head above water, and by a winding course get, with apparent difficulty clear of the creek, where our boat lay, and where the monster seemed in danger of being imbayed. It continued to move off, with its head above water, and with the form somewhat oval. Its neck somewhat smaller. Its shoulders, if I can so term them, considerably broader, and thence it tapered towards the tail, which last it kept pretty low in the water, so that a view of its could not be taken so distinctly as I wished. It had no fin that I could perceive, and seemed to me to move progressively by undulation up and down. Its length I believed to be from 70 to 80 feet; when nearest to me, it did not raise its head wholly above water, so that the neck being under water, I could perceive no shining filaments thereon, if it had any. Its progressive motion under water I took to be rapid, from the shortness of the time it took to come up to the boat. When the head was above water, its motion was not near so quick; and when the head was most elevated it appeared evidently to take a view of distant objects.

Oudemans points out that by the "shining filaments," Maclean means the bristles of the decomposing fins from the basking shark that was the Stronsay Beast. $\mathrm{He}$ is particularly heartened by Maclean's referral to the broad shoulders of the UMO, since it supports his own contention that all such creatures are prehistoric marine mammals and not true snakes. He states that the other behavioral attributes reported by Maclean will be repeated in later sightings throughout the nineteenth century. Maclean's letter also goes on to note that at about the same time of his own sighting, another took place when the crew of the ferry boat from Rum to 
Canna observed a similar animal.

6. For my Scottish Isles conservation biology counterpoint using alternative expert and witness evidence, I note that Oudemans ignores the obvious disparity between the two sightings; namely that the 1808 UMO displayed a prominent "head" above the water, whereas this was not the case for the Leda UMO. Also, there is no mention of a series of humps for the $1808 \mathrm{UMO}$, which is arguably the most overt physical trait displayed by the Leda UMO (Figure 3). In short, it is difficult to reconcile these disparities.

A better Scottish contextual reference for the Leda encounter occurred the following decade. It is telling that Oudemans, contrastingly either emphasising or playing down evidence as he developed his theory that a long-necked paleo-seal is the candidate animal for all sea serpent sightings, ignored linking this 1882 sighting to that of the Leda, given that both are what Heuvelmans (1968) would later refer to as his "many-humped" category of sea monsters, and what I suggest in these two cases to be indicative of entangled basking sharks.

In a July 1882 letter to the newspaper Illustrirte Zeitung (the German equivalent to The Illustrated London News), Captain Weisz of the steamer Kätie describes an encounter of several months prior with an UMO off the Butt of Lewis, the northern tip of the Hebrides (in Oudemans 1892:277):

We observed on the starboard bow, at a distance of about two miles, a dark object lying on the surface, which was only slightly moved by the waves; first we took if for a wreck, as the highest end resembled the bow and the forepart of a ship, and the remaining bumpy part resembled the broken waist of a ship filled with water. As we got nearer we saw with a glass on the left of the visible object, the water moving in a manner, as if the object extended there under the water, and this motion was of the same length as the part of the object visible above the surface. Therefore we took care, not to steer too near, lest the screw should be damaged by some floating pieces of the wreck. But on getting nearer we observed that the object was not a wreck, and, if we had not known with certainty that on these coasts there are no shallows, we should have taken this dark connected row of bumps for rocks. When, however, we changed our course obliquely from the object, which lay quite still all the time, to our astonishment there rose, about eighty feet from the visible end, a fin about ten feet in height, which moved a few times, while the body gradually sank below the surface [Figure 7]. In consequence of this the most elevated end rose, and could distinctly be made out as the tail of a fish of immense dimensions.

The length of the visible part of this animal which had not the least resemblance to the back of a whale, measured, according to our estimation, about 150 feet, the hills, which were from three to four feet in height, and about six or seven feet distant from each other, were smaller on the tail end than on the head end, which withdrew from our observation.

At our arrival at Newcastle, I learned that some days before some fishermen of Lewis had observed the same or similar animal. Had I recognized the object before us, to be one of these creatures, which for so long time belonged to the fables, I should certainly have neared it with the Kätie as much as possible.

Oudemans resorts to some fancy footwork to force-fit the Kätie UMO into his 


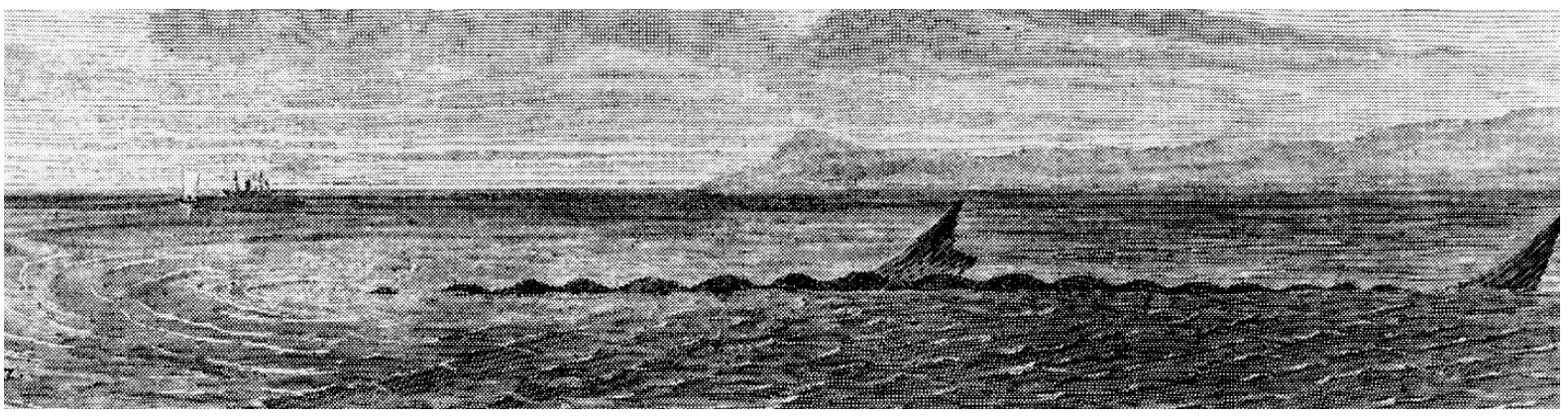

Figure 7. Illustration of the many-humped Kätie UMO observed in the Scottish Hebrides in 1882 (from Captain Weisz in Oudemans 1892), and used herein to suggest that this sighting, like that of the Leda from the same area in the previous decade, were both of non-lethally entangled basking sharks.

one-size-fits-all, paleo-seal typology. While acknowledging that the bunches were displayed even when the animal was motionless or nearly so, he does not address the inconvenient truth that obviously, if this is the case, the dorsal flexure cannot be related to any undulating movement; in short, this UMO, as many others similarly sodescribed, has a body that is compartmentalized into permanently rigid up-and-down segments. $\mathrm{He}$ is rightly disbelieving that any animal could be as long as "150 feet," but concludes that Weisz must have exaggerated the dimensions, rather than countenancing the possibility that the enormous proportions were due to a train of entangled gear or debris. Next, Oudemans twists himself in a pretzel developing a fiction that involves the animal "searching for food in a playful manner" wherein it turns about and raises one of its "hindflappers" and then one of its "foreflappers" in the air as it presumably rolls on its side. It was these appendages, he believes, that were misidentified by the captain and the illustrator (Andrew Schultz, a well-known animal painter) as being a tail, something which had the observers been closer to the animal, Oudemans insists, they certainly would have correctly identified.

The description and especially the illustration strongly suggest the Kätie UMO to have been several, and possibly more, basking sharks, which often swim in a line snout-to-tail, or parallel side-by-side, while feeding on dense patches of plankton (Speedie 2017). The dorsal fins of several sharks are clearly shown, the anterior one possibly displaced slightly to the right side. One can go online to watch scenes from the famous 1934 ethno-fiction film Man of Aran, or read modern accounts of ecotourists in Scotland that describe similar scenes, some of which are accompanied by photographs, all resembling aspects of the Kätie encounter. The difference is that, with respect to the 1882 sighting, it seems that the anterior shark is pulling a train of nonlethally entangled fishing floats, indicated by the 16 humps displayed and described as "lying on the surface."

\section{The Nature of the Beast}

Historical ecology is, as Alexander et al. (2017) correctly state, "a forensic pursuit." In this regard, it is generally an easier task to infer non-lethal entanglement from accounts of sea serpents than it is to theorize about the nature of the animals themselves who are responsible for dragging the debris. This is especially the case when the entangled 
animals do not have to surface to breath. So, whereas it is not difficult to advance that whales wrapped about in presumed combat with enormous snakes, or sea monsters resembling turtles sporting long and narrow tails, are really entangled animals (France 2016a,b), candidate identification it is more difficult when the species is most likely a fish (France 2019). That said, there are similarities between the 1817-19 Gloucester UMO, which I conclude to have been an entangled giant Bluefin tuna, and the 1872 Leda UMO, which I propose to have been, like the Kätie UMO sighting in the same region a decade later, a basking shark. What I suggest to be the entangled strings of netfloats for both UMOs appeared nearly motionless on the surface, giving the impression of the animals basking in the sun, interrupted by sudden and splash-less disappearances. This could indicate that the animal attached to the front-end of the debris train was swimming about underwater, feeding on dense patches of herring in the case of the tuna, or on plankton for the basking shark, normal behavioral traits for these species. Furthermore, in both cases, heads were described based on inferences made that the subtly displayed first of the segmented components in the water were such, rather than obvious crania that were prominently shown above the surface, displaying discernable eyes and mouths. Again, this bespeaks piscine candidates for these entangled animals rather then cetaceans and chelonians.

Basking sharks, more than other species, have a close ethnozoolgical relationship to sea monsters. Indeed, their very taxonomic name, Cetorhinus maximus, means "pointynosed monster." Not without reason, then, did Colin Speedie (2017) entitle his book $A$ Sea Monster's Tale: In Search of the Basking Shark. Often it is the unusual and prodigious size of the animals, which at ten metres is comparable to school buses (Fairfax 1998), that attracts attention and makes Scottish observers think and refer to them as being "monstrous" (Maxwell 1952; Speedie 2017). But it is also their behavior which contributes to them being misconstrued as sea monsters. When filterfeeding on blooms of plankton near the surface, the tips of a basking shark's snout, first dorsal fin, and upper tail lobe are all exposed conspicuously out of the water, and given the size of the beast, often separated by considerable distance. Illustrations and photographs of such surface-swimming basking sharks (Maxwell 1952 Gould 1930; Fairfax 1998) inarguably do look like what the gullible could imagine to be a manyhumped sea serpent. Basking sharks are common in waters along the northwest coast of Scotland, being plentiful enough to sustain commercial fisheries there over a period of centuries (Fairfax 1998) and into modern times (Maxwell 1952; Watkins 1958). By far, they are the most abundant large species of marine life in the region. Not surprisingly, Maxwell (1952) believed that many so-called sea monster sightings were really unrecognized basking sharks. This is something supported by a parsing of the words contained in numerous reports of UMOs from the British Isles compiled by Harrison (2001). Magin (1996) noted that the annual spring migration of basking sharks along the British coast corresponds to the first seasonal reports of seas serpents, and when the sharks depart the area, the sightings cease. Part of this might be due to the propensity of the animals to swim in long lines, nose to tail, which "when seen from a distance they look like nothing other than a sea snake or plesiosaur" (Speedie 2017:18). Speedie provides a modern anecdote of standing beside an individual whom insisted, 
despite being told otherwise, that the distance view of a basking shark off the Scottish coast was a definitive sea serpent as she had often observed.

And these misconstrued sightings were for solitary or several basking sharks which were not entangled in maritime debris. Attach to such an animal the presence of a long, serpent-like "body" or "tail" in the form of a string of herring net floats or harpoon hunting kegs, bouncing on the surface of the water as it is pulled along, and it is no wonder that observers of both the Leda and Kätie UMOs became convinced that they were seeing the famous sea serpent, the subject of frequent discussion in scientific circles at the time.

The entanglement of basking sharks has long been noted. Pontopiddian (1755), for example, provides one of the earliest descriptions of bycatch, with specific reference made to fishermen's concerns about their nets in the presence of the species. Likewise, Wilcocks (1884:182) states that sharks are the "plague" of nineteenth-century British and Scottish fishermen, due to them making "dreadful havoc" among lines and net meshes. During the middle of the twentieth century, the problem became so severe in British Columbia, with hundreds of salmon nets becoming ruined each month, that the government declared basking sharks to be "destructive pests," and instigated a fishery to cull them. It is not a coincidence that this was also the time of a peak in sea serpent sightings in that region of Canada (Wallace and Gisborne 2006). Near the Hebrides, the Irish, during the nineteenth century, actually capitalized on this tendency for basking sharks to become entangled when they established their own specialized, net-based fishery for the animals (Speedie 2017). Fairfax (1998) mentions basking sharks being caught in herring nets set in British Isles' waters during the 1800s, with one animal subsequently put on display due to its monstrous size. It is my contention that basking sharks that have partially but incompletely escaped from such encounters with fishing gear or hunting equipment are, to paraphrase the famous closing line from The Maltese Falcon-a film about another much sought after but ultimately upon careful examination, unremarkable, animal-"the stuff that [sea serpent] dreams are made of."

\section{CONCLUSIONS}

\section{Conservation Biology Implications}

Gauging the full magnitude of anthropogenic impacts upon aquatic ecosystems necessitates estimating their one-time natural conditions. In the absence of detailed historical catch records, researchers have had to imaginatively use novel ethnozoolgical data sources, including, for example, physical artifacts such as trophy photos, repurposed body parts, or fishing gear (McClenachan 2009; Drew et al. 2013; Rice et al. 2017), and textural information from non-traditional anecdotal accounts (Al-Abdulrazzak et al. 2012; France 2016a,b). Studies of shifting baselines with respect to sharks (e.g. Baum and Ransom 2004; Fortibuoni et al. 2016; Ferretti et al. 2018) need to recognize that these populations have been subjected to pressures of not just direct fishery exploitation but also to becoming by-catch resulting from entanglement in that fishing or hunting gear. The present ethnozoological reinterpretation of a handful of accounts of sea serpent sightings from the nineteenth century is important for suggesting that the entanglement of sharks in maritime debris 
has a much longer environmental history than is commonly believed. This paper provides another example of how ethnobiological studies (Saenez-Arroyo et al. 2006; Narchi et al. 2013; Rice et al. 2017; Loveless 2017; Zapelini et al. 2017; France 2019) can contribute toward recognizing past fishing-related pressures and historical shifts in baseline conditions of affected populations.

\section{ENDNOTES}

1 "If this thing looks like those drawings, I'm emptying my clip into it." - Agent Fox Mulder, The X-Files (Season 10: Mulder \& Scully Meet the Were-Monster).

2 "I have never met anyone so passionate and dedicated to a belief as you. It's so intense that sometimes it's blinding." Agent Dana Scully, The X-Files (Season 1: Young at Heart).

\section{REFERENCES}

Aiken W R G, Purser J (1936) The preservation of fibre ropes for use in sea-water. Plymouth Laboratory New Series 20:643-654.

Al-Abdulrazzak D, Naidoo R,.Palomares MLD, Pauly D (2012) Gaining perspective on what we've lost: The reliability of encoded anecdotes in historical ecology. PLOS One 7:1-5.

Alexander KE and others. (2017) Tambora and the mackerel year: Phenology and fisheries during an extreme climate event. Science Advances 3:1-18.

Alves RT, Albuquerque UP (Eds.) (2017). Ethnozoology: Animals in Our Lives. Elsevier.

Anderson, E.N., D. Pearshall, E. Hunn and N. Turner (Eds.) (2011) Ethnobiology. WileyBlackwell.

Anonymous. (2019a) Dead whale was tangled in rope in East Lothian for 'months'. BBC News 25/04/19. www.bbc.com/news/uk-scotlandedinburgh-east-fife-48051954.
Anonymous. (2019b) Whale washed up in Caithness tangled in Canadian fishing gear. BBC News, 03/06/19. www.bbc.com/news/ukscotland-highlands-islands-48497046.

Barclay J (1811) Remarks on some parts of the animal that was cast ashore on the Island of Stronsa. Memoirs of the Wernerian Natural History Society 1:418-444.

Barber L (1980) The Heyday of Natural History 1820-1870. Doubleday \& Company.

Bauer HH (2013) Cryptozoology and the troubles with 'skeptics' and mainstream pundits. Journal of Scientific Exploration 27:690704.

Baum JK, Myers RA (2004) Shifting baselines and the decline of pelagic sharks in the Gulf of Mexico. Ecology Letters 7:135-145.

Bekker-Nielsen T, Casola DB (Eds.) 2010. Ancient Nets and Fishing Gear. Aarhus University Press.

Berger C (1983) Science, God, and Nature in Victorian Canada. University of Toronto Press.

Binns R (1984) The Loch Ness Mystery Solved. W.H. Allen.

Bolster WJ (2012) The Mortal Sea: Fishing the Atlantic in the Age of Sail. Harvard University Press.

Brink-Roby H (2008) Siren canora: The mermaid and the mythical in late nineteenthcentury science. Archives of Natural History 35:1-14.

Brongersma LD (1968) The Soay Beast. Beaufortia 15:33-46.

Brown CM (1990) A natural history of the Gloucester sea serpent: Knowledge, power, and the culture of science in Antebellum America. American Quarterly 42:402-436.

Burns El (2014) Monster on the Margin: The Sea Serpent Phenomenon in New England, 1817-1849. Ph. D. Thesis, Department of History, University of Buffalo.

Burnett DG (2007) Trying Leviathan: The Nineteenth-Century Court Case that Put the Whale on Trial and Challenged the Order of Nature. Princeton University Press.

Burton M (1960) The Soay Beast. The Illustrated London News (June 4, 1960):972-973

Burton M (1961) Was the Soay Beast a tourist? The Illustrated London News (October 14, 1961):632. 
Coleman L,.Huyghe P (2003) The Field Guide to Lake Monsters, Sea Serpents, and Other Mystery Denizens of the Deep. Putman.

Cronon WJ, McDonnell MJ (Eds.) (1993) Humans as Components of Ecosystems: The Ecology of Subtle Human Effects and Populated Areas. Springer.

Crumley CJ (Ed.) (1994) Historical Ecology: Cultural Knowledge and Changing Landscapes. School for Advanced Research Press.

Das N (2009) Occam's Razor and cryptozoology. The Scienta Review. MIT.

da Silva TC, Medeiros PM, Balcázar $A L$, de Sousa Araújo TA, Pirondo A, Trindade Medeiros MF (2014) Historical ethnobiology: An overview of selected studies. Ethnobiology and Conservation

http://dx.doi.org/10.15451/ec2014-6-3.4-1-12

da Silva Vieira K, Da Silva Viera WL, Alves RR (2017) Imaginary zoology: Mysterious fauna in the reports of ancient travelers and chroniclers. In: Alves, R.T. and U.P. Albuquerque (Eds.) 2017. Ethnozoology: Animals in Our Lives. Elsevier.

Davis JF, Gray C, Bigelow J (1817) Report of a committee of the Linnaean Society of New England relative to a large marine animal, supposed to be a serpent, seen near Cape Ann, Massachusetts, in August, 1817. Linnaean Society Private Publication. (online access, numerous sources)

Deedy A (2017) Hark! A sea monster! (Oh, no, just a dying whale). All those strange sea monster sightings in days of yore? This may be the best explanation yet. Hakai Magazine $08 / 02 / 17$.

Dendle P (2006) Cryptozoology in the medieval and modern worlds. Folklore 117:190-206.

Derraik JGB (2002) The pollution of the marine environment by plastic debris: A review. Marine Pollution Bulletin 42:842-852.

Drew J, Philipp C, Westneat MW (2013) Shark tooth weapons from the 19th century reflect shifting baselines in central Pacific predator assemblies. PLOS ONE 8(4): e59855. https://doi.org/10.1371/journal.pone.0059855
Ellis R (1994) Monsters of the Sea. Alfred A. Knopf.

Fairfax D (1998) The Basking Shark in Scotland - Natural History, Fishery and Conservation. Tuckwell Press.

Fama E (2012) Debunking a great New England sea serpent. Tor.com 16/08/12.

Ferretti F, Curnick D, Liu K, Romanow EV, Block BA (2018) Shark baselines and the conservation role of remote coral reef ecosystems. Science Advances 4(3): doi: 10.1126/sciadv.aaq0333.

Fortibuoni T, Borme D, Franceschini G, Giovanardi O, Raicewich S (2016) Common, rare or extirpated? Shifting baselines for common angelshark, Squatina squatina (Elasmobranchii: Squatinidae), in the northern Adriatic Sea (Mediterranean Sea). Hydrobiologia 772:247-259.

France RL (2007) Wetlands of Mass Destruction: Ancient Presage for Contemporary Ecocide in Southern Iraq. Green Frigate Books.

France RL (2016a) Reinterpreting nineteenthcentury accounts of whales battling 'sea serpents' as an illation of early entanglement in pre-plastic fishing gear or maritime debris. International Journal of Maritime History 28:686714.

France RL (2016b) Historicity of sea turtles misidentified as sea monsters: A Case for the early entanglement of marine chelonians in pre-plastic fishing nets and maritime debris. Coriolis: An International Journal of Maritime Studies 6:1-24.

France RL (2017) Imaginary sea monsters and real environmental threats: Reconsidering the famous Osborne, 'Moha-moha', Valhalla, and 'Soay Beast' sightings of unidentified marine objects. International Review of Environmental History 3:63-100.

France RL (2018) Illustration of an 1857 'seaserpent' sighting re-interpreted as an early depiction of cetacean entanglement in maritime debris. Archives of Natural History 45:111-117.

France RL (2019) Disentangled: Ethnozoology and Environmental Explanation of the Gloucester Sea Serpent. Wageningen Academic Publishers. 
Galbreath GJ (2015) The 1848 'enormous serpent' of the Daedalus identified. The Skeptical Inquirer 39(5):42-46.

Gardner D (2007) Whale survives harpoon attack 130 years ago to become 'World's oldest mammal'. The Daily Mail, 13/06/2007.

Goode GB and others. (1884) The Fisheries and Fishery Industries of the United States. National Oceanographic and Atmospheric Administration reprinting. (online access, numerous sources).

Gould RT (1930) The Case for the Sea-Serpent. Philip Allen.

Gregory MR (2009) Environmental implications of plastic debris in marine settings - Entanglement, ingestion, smothering, hangers-on, hitch-hiking and alien invasions. Philosophical Transactions of the Royal Society B 364:2013-2025.

Guizard F (2018) Delfines nec non et ballenae...Les cetaces de l'Atlantique nord au haut Moyen Age: Representation, identification et consummation. Anthropozoologica 53:115-123.

Hamilton J (2003) Scottish Myths and Legends. Lomond Books.

Harrison P (2001) Sea Serpents and Lake Monsters of the British Isles. Robert Hale Ltd.

Hendrikx S (2018) Monstrosities from the sea. Taxonomy and tradition in Conrad Gessner's (1516-1565) discussion of cetaceans and seamonsters. Anthropozoolgica 53:125-137.

Heuvelmans B (1968) In the Wake of the SeaSerpents. Hill and Wang.

Home E (1809) An anatomical account of the Squalus maximus (of Linnaeus) which in the structure of its stomach forms an intermediate link in the gradation of animals between the whale tribe and cartilaginous fishes. Philosophical Transactions of the Royal Society of London 2:206-220.

Houwen L, Olsen KE (2001) Monsters and the Monstrous in Medieval Northwest Europe. Peeters Publishers.

Jacquemard C, Gauvin B, Lucas-Avenel M-A, Clavel B (2018) Animaux aquatiques et monstres des mers septentrionales (imaginer, connaitre, exploiter, de l'Antinquite a 1600). Anthropozologica 53. Special issue.
Johnson T (2005) Entanglements: The Intertwined Fates of Whales and Fishermen. University Press of Florida.

Kristjonsson H (1971) Modern Fishing Gear of the World 3: Fishing Gear, Purse Seining, Aimed Trawling. Food and Agriculture Organization.

Laist DW (1997) Impacts of marine debris: Entanglement of marine life in marine debris including a comprehensive list of species with entanglement and ingestion records. In Coe JM, Rogers DB (Eds.), Marine Debris.

LeClercq-Marx J (2018) Entre tradition classique et imaginarie germane-celtique: Les monstres anthropomorphes des mers septentrionales, au Moyen Age et au debut de l'epoque modern. Antrhopozoologica 53:53-65.

Lehn WH (1979) Atmospheric refraction and lake monsters. Science 205:183-185.

Lehn WH, Schroeder I (1981) The Norse merman as an optical phenomenon. Nature 293:362-366.

Lee H (1883) Sea Monsters Unmasked. William Clowes and Sons.

Lotze HK and others. (2006) Depletion, degradation, and recovery potential of estuaries and coastal seas. Science 312:18061809.

Loveless E (2017) Ethnoarchaeology can be used for ecological conservation because it can detect shifting baselines. Arizona Anthropologist 28:51-65.

Loxton D, Prothero DR (2015) Abominable Science!: Yeti, Nessie, and other Famous Cryptids. Columbia University Press.

Lyons SL (2009) Species, Serpents, Spirits, and Skulls: Science at the Margins in the Victorian Age. SUNY Press.

Macrae J, Twopeny D (1873) Appearance of an animal, believed to be that which is called the Norwegian sea-serpent, on the western coast of Scotland, in August, 1872. The Zoologist 2(8):3517-3522.

Magin U (1996) St George without a dragon. Bernard Heuvelmans and the sea serpent. Fortean Studies 4:223-234.

Mason A (2017) An ocean in the parlor: Home aquariums were the newest fad in the natural history-crazed Victorian era. Hakai Magazine, March 24. 12p. 
Maxwell G (1952) Harpoon at a Venture. R. Hart-Davis.

McCaskill J (2009) Conserving Waterlogged Rope: A Review of Traditional Methods and Experimental Research with Polyethylene Glycol. MA Thesis, Texas A\&M University.

McClenachan L (2009) Documenting loss of large trophy fish from the Florida Keys with historical photographs. Conservation Biology 23:636-643.

McClenachan L, Ferretti F, Baum JK (2012) From archives to conservation: Why historical data are needed to set baselines for marine animals and ecosystems. Conservations Letters 5:349-359.

McGowan-Hartman J (2013) Shadow of the dragon: The convergence of myth and science in nineteenth century paleontological imagery. Journal of Social History 47:47-70.

McEwan GJ (1978) Sea Serpents, Sailors \& Sceptics. Routledge.

Meine C (1999) It's about time: Conservation biology and history. Conservation Biology 13:13.

Mitchell SL (1829) The history of seaserpentism. American Journal of Science and Arts 15:351-356.

Mowat F (1997) Sea of Slaughter. McClellandBantam.

Narchi NE, Cornier S, Canu DM, Aguilar-Rosas LE, Bender MG, Jacquelin C, Thiba M, Moura GGM, de Wit R (2013) Marine ethnobiology a rather neglected area, which can provide an important contribution to ocean and coastal management. Ocean \& Coastal Management 89:117-126.

National Oceanic and Atmospheric Administration (2014) Report on the Entanglement of Marine Species in Marine Debris with an Emphasis on Species in the United States. Silver Spring, MD: National Oceanic and Atmospheric Administration Marine Debris Program.

O'Neill JP (1999) The Great New England Sea Serpent: An Account of Unknown Creatures Sighted by Many Respectable Persons Between 1638 and the Present Day. Down East Books.

Oudemans AC (1892) The Great Sea-Serpent. Coachwhip Publications (2007 facsimile reprinting).
Parsons ECM (2004) Sea monsters and mermaids in Scottish folklore: Can these tales give us information on the historic occurrence of marine animals in Scotland? Anthrozoös 17:73-80.

Pauly D (1995) Anecdotes and the shifting baseline syndrome of fisheries. Trends in Ecology and Evolution 10:430.

Paxton CGM (2009) The plural of 'anecdote' can be 'data': Statistical analysis of viewing distances in reports of unidentified large marine animals 1758-2000. Journal of Zoology 279:381-387.

Paxton CGM, Holland R (2005) Was Steenstrup right? A new interpretation of the $16^{\text {th }}$ century sea monk of the Oresund. Steenstrupia 29:3947.

Paxton CGM, Knatterud E, Hedley SL (2005) Cetaceans, sex and sea serpents: An analysis of the Egede accounts of a 'most dreadful monster' seen off the coast of Greenland in 1734. Archives of Natural History 32:1-9.

Paxton CGM, Naish D (2019) Did nineteenth century marine vertebrate fossil discoveries influence sea serpent reports? Earth Sciences History 38:16-27.

Pitcher T (2005) Back-to-the-future: a fresh policy initiative for fisheries and a restoration ecology for ocean ecosystems. Philosophical Transactions of the Royal Society B 360:107-121.

Pontopiddian E L (1755) The Natural History of Norway. A. Linde (online access).

Regal B (2012) Richard Owen and the seaserpent. Endeavor 36: 65-68.

Rice PM, Rice DS, Pugh TW (2017) Small Things Forgotten: Artifacts of Fishing in the Petén Lakes Region, Guatemala. Contributions in Ethnobiology.

Ritvo H (1997) The Platypus and the Mermaid and Other Figments of the Classifying Imagination. Harvard University Press.

Ritvo H (2010) Noble Cows and Hybrid Zebras: Essays on Animals and History. University of Virginia Press.

Rossi L (2016) A review of cryptozoology: Towards a scientific approach to the study of 'hidden animals.' In: Angelici FM (Ed.) Problematic Wildlife. Springer. 
Saenz-Arroyo A, Roberts CM, Torre J, CarinoOlvera M (2005) Using fishers' anecdotes, naturalists' observations and grey literature to reassess marine species at risk: The case of the Gulf grouper in the Gulf of California, Mexico. Fish and Fisheries 6:121-133.

Saenz-Arroyo A, Roberts CM, Torre J, CarinoOlvera M, Hawkins JP (2006) The value of evidence about past abundance: Marine fauna of the Gulf of California through the eyes of $16^{\text {th }}$ to $19^{\text {th }}$ century travellers. Fish and Fisheries 7:128-146.

Sargent CL (1818) The Sea Serpent. Evidence About It. Unpublished manuscript. Sole copy in Cape Ann Museum Archives.

Shermer M (2003) Show me the body. Scientific American 288:37.

Soini W (2010) Gloucester's Sea Serpent. The History Press.

Speedie C (2017) A Sea Monster's Tale: In Search of the Basking Shark. Wild Nature Press.

Starkey LJ (2017) Why sea monsters surround the northern lands: Olaus Magnus's conception of water. Preternature 6:31-62.

Svanberg I (1999) The brother of the snake and fish as kings. Frodskaparrit 47: 129-138.

Sweeney JB (1972) A Pictorial History of Sea Monsters and Other Dangerous Marine Life. Nelson-Crown.

Swinney G (1983) The Stronsay monster: A case of mistaken identity. Journal of Marine Education 4:15-17.

Szabo P, Hedl R (2011) Advancing the integration of history and ecology for conservation. Conservation Biology 25: 680687.

Szabo VE (2008) Monstrous Fishes and the Mead-Dark Sea: Whaling in the Medieval North Atlantic. Brill.

Szabo V (2018) Northern seas, marine monsters, and perceptions of the premodern North Atlantic in the longue durée. In Visions of North in Premodern Europe, Ed. Jorgensen D, Langum V pp. 145-182. Brepols Publishers.

Teit JA (1918) Water-beings in Shetlandic folklore, as remembered by Shetlanders in British Columbia. Journal of American Folklore 31:180201.
Tidermann S, Gosler A (Eds.) 2010. Ethnoornithology: Birds, Indigenous Peoples, Culture and Society. Routledge.

Traill TS (1854) On the supposed sea snake cast on shore in the Orkneys in 1808, and the animal seen from H.M.S. Daedalus in 1848. Proceedings of the Royal Society of Edinburgh. 3:208-215.

Vegter AC and others. (2014) Global research priorities to mitigate plastic pollution impacts on marine wildlife. Endangered Species Research 25:225-247.

Wabnitz C, Nicols WJ (2010) Plastic pollution: An ocean emergency. Marine Turtle Newsletter 129:1-4.

Wallace S, Gisborne B (2006) Basking Sharks: The Slaughter of B.C.'s Gentle Giants. Transmonanus.

Watkins A (1958) The Sea My Hunting Ground. Heinemann.

Westrum R (1979) Knowledge about sea serpents. In Wallis $\mathrm{R}$ (Ed.) On the Margins of Science: The Social Construction of Rejected Knowledge. University of Keele.

Williams G (2015) A Monstrous Commotion: The Mysteries of Loch Ness. Orion Books.

Woodley MA (2008) In the Wake of Bernard Heuvelmans: An Introduction to the History and Future of Sea Serpent Classification. CFZ Press.

Woodley MA, Naish D, McCormick CA (2012) A baby sea-serpent no more: Reinterpreting Hagelund's juvenile 'Cabororsaur' report. Journal of Scientific Exploration 25:497-514.

Zapelini C, Giglio VJ, Carvalho RC, Bender MG, Gerhardinger LC (2017) Assessing fishing experts' knowledge to improve conservation strategies for an endangered grouper in the southwestern Atlantic. Journal of Ethnobiology $37: 478-493$

Received: 10 July 2019

Accepted: 08 August 2019

Published: 12 October 2019 